DOE/FETC-98/1059

\title{
Results of Stoker Testing on CONSOL Fuels CRADA PC90-003, Final Report
}

\author{
December 18, 1992
}

\author{
U.S. Department of Energy \\ Pittsburgh Energy Technology Center \\ 626 Cochrans Mills Road \\ Pittsburgh, PA 15236 \\ and \\ Consolidation Coal Co. \\ 4000 Brownsville Road \\ Library, PA 15129
}

\section{DISCLAIMER}

This report was prepared as an account of work sponsored by an agency of the United States Government. Neither the United States Government nor any agency thereof, nor any of their employees, makes any warranty, express or implied, or assumes any legal liability or responsibility for the accuracy, completeness, or usefulness of any information, apparatus, product, or process disclosed, or represents that its use would not infringe privately owned rights. Reference herein to any specific commercial product, process, or service by trade name, trademark, manufacturer, or otherwise does not necessarily constitute or imply its endorsement, recommendation, or favoring by the United States Government or any agency thereof. The views and opinions of authors expressed herein do not necessarily state or reflect those of the United States Government or any agency thereof. 


\section{DISCLAIMER}

Portions of this document may be illegible electronic image products. Images are produced from the best available original document. 


\section{Results of Stoker Testing on CONSOL Fuels}

\section{FUEL DESCRIPTION}

Combustion and emissions data are reported for the following fuels relevant to the CONSOL CRADA:

Pittsburgh (Bailey Mine)

Parent Stoker

Extrusion $w /$ paper additive

Extrusion w/ paper additive - dried

Extrusion w/ RDF (50/50 coal/RDF) (RDF5)

Extrusion w/ RDF (70/30 coal/RDF) (RDF2)
Pocahontas \#3 (Buchanan Mine)

Parent Stoker

Briquette $5 \mathrm{cc}$ (no sorbent)

Briquette $1 \mathrm{cc}$ w/ Hydrated Lime $(\mathrm{Ca} / \mathrm{S}=3)$

Briquette $1 \mathrm{cc}$ w/ Coke Fines

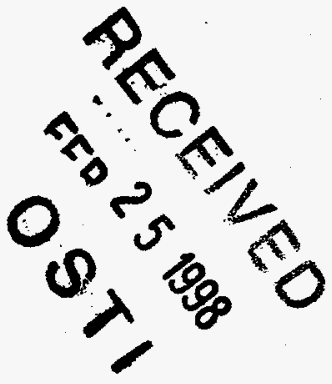

All of these fuels have been tested in the warm-air furnace at a firing-rate of approximately $150,000 \mathrm{Btu} / \mathrm{hr}$. Two fuels (Pocahontas briquettes - sorbentless and hydrated lime) were tested in the cast-iron boiler at a firing-rate of approximately $1.8 \mathrm{MMBtu} / \mathrm{hr}$.

Tables 1 and 2 summarize the pertinent analyses for these fuels. In general, the data are consistent although there appears to be discrepancies, particularly for the heating values and moisture content of the RDF-containing fuels.

\section{STOKER TEST FACILITIES}

\section{Residentiai Warm-Air Furnace (WAF)}

The WAF is a typical $225,000 \mathrm{Btu} / \mathrm{hr}$ (thermal input) residential warm-air furnace which is equipped with an underfeed stoker to normally deliver $16 \mathrm{lb} / \mathrm{hr}$ of coal solids, with two additionai speeds at 12 and $20 \mathrm{lb} / \mathrm{hr}$. At a typical warm air blower pressure of 0.1 in $\mathrm{H}_{2} \mathrm{O}$, $1100 \mathrm{scfm}$ of hot air in the $150-225^{\circ} \mathrm{F}$ range can be produced depending upon the air intake temperaure and furnace firing rate. The furnace/underfeed stoker was manufactured by the Will-Bur Company. A cross-sectional diagram of the commercially-available system is presented in Figure 1. The WAF test facility has a two-fold purpose: first, to establish a residentiai emissions data base under continuous, cyclic, and hold-fire operations; and second, to serve as a screening furnace for limited quantities of reconstituted coal fuels. On the latter issue, the WAF requires about $120 \mathrm{lb}$ of fuel per test day. The WAF furnace was modified and heavily instrumented in order to provide research quality measurements while operating the furnace in a realistic manner.

Before ceaailing the various system modifications, it is useful to summarize the basic principles of residential stoker operation. In typical off-the-sheif underfeed stoker designs. 
Table 1: Pocahontas \#3 Stoker and Agglomerated (Briquetted) Fuel Analyses

\begin{tabular}{|c|c|c|c|c|c|}
\hline & $\begin{array}{l}\text { Pcy/Coke } \\
\text { Briquette } \\
\text { (ivilsor) }\end{array}$ & $\begin{array}{c}\text { Pcy/Coke }{ }^{(e)} \\
\text { Briquette } \\
\text { (:int:ilul }\end{array}$ & $\begin{array}{l}\text { Pcy/lime } \\
\text { Briquette } \\
\text { Illit: }\end{array}$ & $\begin{array}{c}\mathrm{Pcy} / 5 \mathrm{ccc}^{(b)} \\
\text { Briquetto } \\
\text { (:oilsolol }\end{array}$ & $\begin{array}{l}\text { Pcylol } \\
\text { Stoker } \\
\text { Co(11):ol) }\end{array}$ \\
\hline \multicolumn{6}{|l|}{ Proximate $(\%)$} \\
\hline Moisture & 1.33 & 1.31 & 1.78 & & 1.07 \\
\hline Volatile Matter & 10.37 & NA & 20.42 & & 19.14 \\
\hline Fixed Carbon & 80.42 & NA & 65.65 & & 73.14 \\
\hline Ash & 7.88 & 8.20 & 12.15 & & 6.65 \\
\hline \multicolumn{6}{|l|}{ Ultimate $(\%$ dry) } \\
\hline Hydrogen & 2.48 & 2.38 & 3.96 & & 4.11 \\
\hline Carbon & 85.22 & 87.07 & 79.13 & & 85.29 \\
\hline Nitrogen & 0.94 & 1.12 & 1.00 & & 1.07 \\
\hline Sulfur & 0.71 & 0.69 & 0.60 & & 0.83 \\
\hline Oxygen & 2.68 & 0.44 & 2.92 & & 1.98 \\
\hline Ash & 7.99 & 8.30 & 12.37 & & 6.72 \\
\hline$H H V(B t u / h b$ AR) & 13460 & 13440 & 13545 & & 14539 \\
\hline FSI & 1.0 & NA & 1.5 & & 6.0 \\
\hline \multicolumn{6}{|l|}{ AST Profile $\left({ }^{\circ} \mathrm{F}\right)$} \\
\hline Initial & 2073 & NA & 2460 & & 2176 \\
\hline Softening & 2087 & NA & 2509 & & 2319 \\
\hline Hemi & 2106 & NA & 2592 & & 2375 \\
\hline Fluid & 2409 & NA & 2654 & & 2422 \\
\hline \multicolumn{6}{|l|}{ L.1s/MMBtu (max) } \\
\hline $\mathrm{SO}_{2}$ (f) & 1.04 & 1.01 & 0.94 & & 1.13 \\
\hline $\mathrm{NO}_{2}(\mathrm{f})$ & 2.26 & 2.70 & 2.38 & & 2.39 \\
\hline
\end{tabular}

Table Notes

(a) fuels analyzed by Consol. All others were analyzed by PETC.

(b) fuel analysis is pending. For now, calculations are based on the parent coal determinations.

(e) denotes an estimate based on the reported percentages of fuel components.

(f) assumes that all sulfur is converted to $\mathrm{SO}_{2}$ and that all fuel nitrogen is converted to $\mathrm{NO}_{2}$. 
Table 2: Pittsburgh Stoker and Agglomerated (Extruded) Fuel Analyses

\begin{tabular}{|c|c|c|c|c|c|c|c|}
\hline & $\begin{array}{l}\mathrm{Pgh} / \mathrm{RDF}^{(\mathrm{s})} \\
\text { Extrusion } \\
\text { Coulsol }\end{array}$ & $\begin{array}{c}\text { Pgh/RDF2 } \\
\text { Extrusion } \\
\text { Comisol }\end{array}$ & $\begin{array}{l}\text { Pgh/RDF5 } \\
\text { Extrusion } \\
\text { (Cortioul }\end{array}$ & $\begin{array}{c}\text { Pgh/RDF5 } \\
\text { Extrusion } \\
\text { Coulsol }\end{array}$ & $\begin{array}{l}\text { Pgh/Pap (ar) } \\
\text { Extrusion } \\
\text { Consol }\end{array}$ & $\begin{array}{c}\text { Pgh/Pap (dry) } \\
\text { Extrusion } \\
\text { Coulsol }\end{array}$ & $\begin{array}{l}\text { Puh } \\
\text { Stoke: } \\
\text { (intusol }\end{array}$ \\
\hline \multicolumn{8}{|l|}{ Proximate $(\%)$} \\
\hline Moisture & $12.00 \mathrm{e}$ & 4.04 & $12.00 \mathrm{e}$ & 4.52 & 19.14 & 1.08 & 1.84 \\
\hline Volatile Matter & $42.94 \mathrm{e}$ & 46.91 & $49.54 \mathrm{e}$ & 44.65 & 31.81 & & 39.81 \\
\hline Fixed Carbon & $34.06 \mathrm{e}$ & 36.10 & $28.25 \mathrm{e}$ & 37.84 & 41.03 & & 51.83 \\
\hline Ash & $10.91 \mathrm{e}$ & 12.95 & $10.21 \mathrm{e}$ & 12.99 & 8.10 & & 6.52 \\
\hline \multicolumn{8}{|l|}{ Ultimate (\% dry) } \\
\hline Hydrogen & 5.09 & 5.25 & 5.35 & 4.91 & 4.82 & & 5.16 \\
\hline Carbon & 66.02 & 63.35 & 61.71 & 63.21 & 72.67 & & 78.14 \\
\hline Nitrogen & 1.11 & 1.09 & 0.96 & 1.02 & 1.20 & & 1.59 \\
\hline Sulfur & 1.31 & 1.37 & 0.99 & 1.09 & 1.45 & & 2.02 \\
\hline Oxygen & 13.70 & 15.44 & 19.14 & 16.16 & 9.84 & & 6.45 \\
\hline Ash & 12.54 & 13.49 & 11.56 & 13.60 & 10.01 & & 6.64 \\
\hline HitV (Btu/lb AR) & $10105 \mathrm{e}$ & 10770 & $9064 \mathrm{e}$ & 10563 & 10125 & 12520 & 13764 \\
\hline FSI & NA & 3.5 & NA & 0.5 & 3.0 & & 8.0 \\
\hline \multicolumn{8}{|l|}{ AST Profile ("F) } \\
\hline Initial & NA & 2051 & NA & 2018 & 2151 & & 2036 \\
\hline Softening & NA & 2092 & NA & 2077 & 2190 & & 2093 \\
\hline Hemi & NA & 2144 & NA & 2133 & 2211 & & 2127 \\
\hline Fluid & NA & 2179 & NA & 2324 & 2236 & & 2243 \\
\hline \multicolumn{8}{|l|}{ Lo/MMBtu (Inax) } \\
\hline $\mathrm{SO}_{2}(\mathrm{f})$ & 2.28 & 2.44 & 1.92 & 1.97 & 2.27 & & 2.88 \\
\hline $\mathrm{NO}_{3}(\mathrm{f})$ & 3.18 & 1.94 & 3.06 & 3.03 & 3.08 & & 3.73 \\
\hline
\end{tabular}

Table Notes

(a) fuels analyzed by Consol. All others were analyzed by PETC.

(b) fuel analysis is pending. For now, calculations are based on the parent coal determinations.

(e) denotes an estimate based on the reported percentages of fuel components.

(t) assunes that all sulfur is converted to $\mathrm{SO}_{2}$ and that all fuel nitrogen is converted to $\mathrm{NO}_{2}$. 
air flow is regulated by the arrangement of several dampers in key locations to ensure satisfactory combustion air flow based upon fuel bed resistance. Coal is conveyed through a screw tube and up into the inner hollow pit (retort) whereby it undergoes increasingly severe changes beginning with devolatilization and ending with combustion, characterized by a yellow-orange flame. Combustion air enters the retort about $1 / 3$ down from its brim througn several rows of small air holes known as tuyeres. The key characteristic of the underreed is its ever-changing, irregular fuel bed as coke constantly forms, falls, and burns. This behavior is dependent on stoker design, operating conditions, fuel particle size, and most importantly, fuel type. In general, the highest portions of the fuel bed can be one foot above the top of the retort. The combustion air is mechanically linked to the stoker motor to accommodate both the coal feed and burning rate; thus, as the fuel bed resistance increases, the combustion air back pressure increases. This causes the damper to open more. thereby allowing more combustion air to burn off the excess inventory. Overfire air occurs via air leakage through small slats in the firebox door. Typical recommended draft for these systems is $0.03-0.06$ in of $\mathrm{H}_{2} \mathrm{O}$. Unfortunately, the delicate balance of gas pressure variation does not permit the inclusion of additional flow resistances, including metering.

To provide flow metering capability, the built-in combustion air blower was replaced with a more powerful blower to permit installation of a venturi and pneumatically-controlled buttertly valve. Similarly, an induced draft fan on the stack permits flue gas flow metering (orifice) and control (pneumatic valve). A calibrated rotary meter was used to standardize the orinice and venturi meters to ensure consistent flow monitoring. With the modified systems. draft and overfire air flow control is extremely consistent even under cyclic (combustion air on/off) operation which characterizes residential heating. Figure 2 presents the overall flow schematic of the WAF test facility.

Other modifications included the installation of a 1) variable-speed motor to improve fuel firing consistency and minimize the effects of fuel density variability (coals vs. briquettes) on auger feed rates, 2) nitrogen purge line to the firebox in order to quench the fire at the end of testing, and 3) sight port for visual observations, video recording, and dual-color pyrometer measurements of the firebox during testing.

\section{Commercial Cast-Iron Boiler (CIB)}

The CIB is a H.B. Smith M450L 11-sectional commercial cast-iron boiler capable of producing hot water or low pressure steam with a designed firing rate of $3.24 \mathrm{MMBtu} / \mathrm{hr}$ for gas and fuel oil. The CIB was originally used to study coal water mixture firing using a PETC-patented rotary cup burner. The CIB was retrofitted with a Worley HW-9 underfeed stoker ithree speed $175 \mathrm{lb} / \mathrm{hr}, 120 \mathrm{lb} / \mathrm{hr}$, and $75 \mathrm{lb} / \mathrm{hr}$ ) to achieve a designed coal-firing rate of 2.6 $\mathrm{MMBtu} / \mathrm{hr}$ which is the equivalent of the H.B. Smith 11 -sectional Model 451 stoker boiler.

The CIB has a closed loop water system in which the boiler inlet and exit temperatures are 
controlled at $160^{\circ} \mathrm{F}$ and $180^{\circ} \mathrm{F}$, respectively. A site cooling tower provides external heat exchange for the boiler captive water loop. The CIB is essentially similar to the WAF in terms of the basic components and operation. Both units have variable speed auger drives to allow testing at constant firing rates. Nitrogen purge lines similarly allow quenching of the fire at the end of each test.

Figure 3 is an overall flow schematic of the CIB system which includes a cyclone and baghouse for particulate control. CIB instrumentation is similar to the WAF in that the combustion air and flue gas flow are metered, having been standardized with a calibrated turbine meter. Unlike the WAF, the CIB has a separate, metered source of overfire air that, during operation, is injected directly into the firebox.

\section{Analytical Instrumentation}

The WAF and CIB are well instrumented in gas analyzer monitoring. A Beckman Model 865 nondispersive infrared analyzer was used to track carbon monoxide $(0-5000 \mathrm{ppm})$ continuousiy while a Beckman Model 880 analyzer provided additional CO measurement in the $0-500 \mathrm{ppm}$ range. This arrangement allows accurate, continuous monitoring of $\mathrm{CO}$ without changing analyzer ranges during WAF operations. Similarly, two total hydrocarbon (THC) analyzers were employed during tests: a Beckman Model 400A was set at the 0-10 ppm range during continuous tests and a Beckman Model 400 analyzer provided coverage at 0-100 ppm. A Thermo Electron Model 10 chemiluminescent analyzer was used to track $\mathrm{NO}_{\mathrm{x}}$ emissions in the $0-1000 \mathrm{ppm}$ range. A Beckman Model 755A paramagnetic oxygen analyzer was employed at the $0-25 \%$ level while carbon dioxide $(0-20 \%$ range) was measured with either a Beckman Model 865 or Model 880 infrared analyzer. Sulfur dioxide measurements are accomplished in combination at medium/high $\mathrm{SO}_{2}$ concentrations with a Beckman Model 865 (0-2000 ppm) and/or Horiba PIR-2000 (0-1000 ppm and 0-5000 ppm) analyzers, and at low $\mathrm{SO}_{2}$ concentrations with a moisture-compensated Horiba VIA-200 (0$200 \mathrm{ppm}$ ) nondispersive infrared analyzer.

The WAF gas sample was conditioned prior to analyzer measurement by continuously withdrawing the sample through a Mott Metallurgical 2-in diameter cylindrical, sintered stainless steel filter of 5 -micron pore size for removal of particulates. To remove moisture, the sample passes through coiled tubing submerged in a $32^{\circ} \mathrm{F}$ ice bath prior to flue gas analysis. Vapor-liquid equilibrium calculations $\left(\mathrm{SO}_{2} / \mathrm{H}_{2} \mathrm{O}\right)$ and ion chromatography measurements of the condensate revealed an acceptably low removal of $\mathrm{SO}_{2}$ during moisture knockout. However, because of the inherent interference between $\mathrm{H}_{2} \mathrm{O}$ and $\mathrm{SO}_{2}$ with IR absorption. a Permapure drier was installed to remove residual sample moisture from the ice bath-conditioned stream prior to the $\mathrm{SO}_{2}$ analyzers. Otherwise, a $32^{\circ} \mathrm{F}$ dewpoint could produce an interference of about $6 \mathrm{ppm} \mathrm{SO} \mathrm{S}_{2}$ based on the typically accepted interference ratio $\left(100 \mathrm{ppm} \mathrm{H}_{2} \mathrm{O}=1 \mathrm{ppm} \mathrm{SO} \mathrm{S}_{2}\right)$ with infrared $\mathrm{SO}_{2}$ analyzers. 


\section{WAF Combustion/Emissions Screening Procedure}

Screening tests are conducted in the WAF under continuous firing based on the desire to mimic the conditions found in large commercial and industrial boilers. Typically, a $1-\mathrm{hr}$ feedscrew test was performed to reveal fuel grindability and determine auger feed (rpm) settings needed to achieve an approximate constant firing rate of $150,000 \mathrm{Btu} / \mathrm{hr}$ (input). This point became important when earlier studies revealed that some fuels fed as much as $50 \%$ faster than the stoker coals. Feedscrew tests also reveal the degree of fuel degradation which is an important consideration in comparing the novel coal-based fuels with stoker coals.

After the feedscrew test, fresh fuel (2-4 lb) and wood kindling were placed over the retort. After lighting, combustion air was initiated for 10-15 minutes to establish the fire before initiation of coal feed. Typically, a warmup period was conducted to establish the proper amount of combustion and overfire air. Initial conditions were set at $50 \%$ excess combustion air plus an additional $50 \mathrm{lb} / \mathrm{hr}$ of overfire air and then altered, if necessary, to achieve more optimum combustion for the subsequent formal 6-hour test period. During this period, air flows were generaily constant and only occasional adjustments were made to ensure a good test burn. Bed temperatures were obtained with a Capintec Instruments, Inc. Ratio-Scope Model III dual-wavelength infrared pyrometer.

At the end of each test, combustion air and fuel feed were turned off; the firebox was allowed to cool for 10 minutes before flooding with nitrogen to extinguish the fire. The firebox ash was then partitioned into three categories according to its stage of combustion powder ash, gray ash, and black ash/coke - to more carefully scrutinize combustion results. Powder ash consisted of the most well-burned, finely divided $(-1 / 4$ in) material relative to the other two fractions. Gray ash consists of larger pieces (plus $1 / 4$ in) while black ash/coke results from the least combustion. The partitioned ash samples are then separately weighed, crushed, riffled, and analyzed.

The selected $150,000 \mathrm{Btu} / \mathrm{hr}$ firing rate was found to produce intense combustion conditions without overheating the carbon steel internal furnace components. The principal guideline here was to ensure that the flue gas exit temperature was below $950^{\circ} \mathrm{F}$. While average flue gas temperatures were in the $700-800^{\circ} \mathrm{F}$ range at the $150,000 \mathrm{Btu} / \mathrm{hr}$ firing rate, significant temperature excursions can occur, particularly for coking coals which can exhibit wide variances in burning rate. With respect to the WAF, several points are noteworthy. First, the older domestic U.S. stokers were not optimally designed for thermal efficiency, as the WAF is approximately $55 \%$ thermally efficient. Thermal efficiency can be dramatically improved upon considering the $80 \%$ values reported for newer European (e.g. Britain) domestic coal-fired furnaces. Second, domestic stokers are really meant for cyclic (on/off) operation to meet variable heating demands throughout the days and years of the homeowner residence. In several older stoker studies, on cycle operation (in minutes) at full load was geared towards achieving a $900^{\circ} \mathrm{F}$ flue gas exit temperature before the onset of the off cycle. Finally. WAF operation at $150,000 \mathrm{Btu} / \mathrm{hr}$ did not produce an excessive quantity of firebox 
ash over the test period.

The initiaily targeted (about 50\% excess air equivalent) combustion air flow through the retort was found to be sufficient for the better burning fuels. In reviewing the available literature. stoker testing has been reported at combustion air levels ranging from $20 \%$ to $300 \%$ excess air equivalent, although the majority of testing has occurred at the lower excess combustion air levels. In general, higher combustion air flows have been proposed as a means of improving combustion of caking stoker coals.

WAF testing, however, revealed that high combustion air flows could produce two unfavorable conditions in the fuel bed. One is the possible formation of large quantities of sparklers (burning fine particulate), depending upon the extent of feedscrew degradation, which effectively poses an upper limit on "realistic" combustion air flow settings. Vendor operation instructions advise against operations resulting in sparkler formation due to various considerations, such as excessive particulate carryover and dangers associated with sparks escaping from the firebox door which is under only a very slight $\left(0.03-0.06\right.$ in $\left.\mathrm{H}_{2} \mathrm{O}\right)$ draft.

Another undesirable result of excessive combustion air is the tendency for intense combustion to occur deep inside the retort cup rather than the vendor recommendation of 4-6" above the retort brim. This problem can be particularly troublesome for highly caking fuels for several reasons. In caking fuel beds, combustion rates are substantially less than that based on the fuel feed rate for significant periods of time. Since the most intense combustion naturally tends to occur at the retort periphery (in the vicinity of the tuyeres) and the highly caking fuels produce large/tall coke trees in the center of the bed, it is difficult to prevent the bed from burning deep inside the periphery of the fuel bed, where local air-to-(burning) fuel ratios are high. Clearly, the worst condition is a highly caking fuel which is heavily weighted with fines.

The initiaily targeted overfire air (about $50 \mathrm{lb} / \mathrm{hr}$ ) was essentially determined after adjusting the furnace draft and firebox slat openings to a "typical" condition as judged by a visiting Will-Burt representative during early WAF testing. This arrangement corresponds to approximately $20-25 \%$ of the total air flow based on operation at a $150,000 \mathrm{Btu} / \mathrm{hr}$ firing rate using the above combustion air (50\% excess air equivalent) flow. This level of overfire air is reasonable based on the majority of existing literature. The study of overfire air effects has not been aggressively pursued in the WAF due to the fact that results might be dependent on many factors (e.g., gas flow patterns, temperature, composition) related to the localized burning/coking zones of the fuel bed.

\section{CIB Comoustion/Emissions Screening Procedure}

CIB screening tests are conducted in similar fashion to the WAF, although a longer $1-1.5$ hour warm-up period is needed before testing at the desired continuous firing rate. This gradual uarm-up period minimizes the possibility of cracking refractory surfaces and ensures 
good combustion as the firing rate is increased. Unlike the WAF, the CIB can not be operated at high loads from a relatively cold start as fresh fuel will rapidly pile up in the retorr. The 1-1.5 hour warmup period, in which the firing rate is slowly increased, has been shown to alleviate this problem. The CIB operational procedure is summarized below.

Feedscrew tests were performed to reveal fuel grindability and determine auger feed (rpm) settings needed to achieve an approximate constant firing rate of $1.8 \mathrm{MMBtu} / \mathrm{hr}$ (input). One point of interest was that the feed variability (lb/hr per auger $\mathrm{rpm}$ ) was much less in the CIB (high/low values within 15\% spread) than that found (high and low values within 50\% spread) in the WAF.

After the warmup period, initial formal test conditions were set at $50 \%$ excess combustion air plus an additional $150-250 \mathrm{lb} / \mathrm{hr}$ of overfire air and then altered, if necessary, to achieve more optimum combustion for the subsequent formal 6 -hour test period. During this period, air flows were generally constant and only occasional adjustments were made to ensure a good test burn. Bed temperatures were obtained (in similar fashion as the WAF) with a Capintec Instruments, Inc. Ratio-Scope Model III dual-wavelength infrared pyrometer.

It should be noted that the relative overfire-to-total-air-flow ratio is lower for CIB operations (in the $10 \%$ range) than that employed in the WAF screening tests in the $30 \%$ range. In prior CIB tests at higher overfire air flows, sight port observations revealed that the fire could become considerably cooled and deflected (towards the front of the boiler) in certain instances. Such visual observations are used to supplement calculated (e.g., burning rate, emissions) values to determine appropriate operating conditions. In comparing the $\mathrm{CIB}$ and WAF overfire air systems, differences in overfire air source (CIB uses 15 psig compressed air; WAF uses ambient draft air), nozzle diameter/number (CIB has four 1-in nozzles; WAF has tweive 0.5 -in holes), and nozzle height (CIB nozzle 15 in above retort; WAF slat openings 20 in above retort) probably contribute to these observations.

At the end of each test, combustion air and fuel feed were turned off; the firebox was allowed to cool for 10 minutes before flooding with nitrogen to extinguish the fire. The firebox ash was then vacuumed out of the furnace. It appears that the coking characteristics of the parent coals are more suppressed than that observed previously in the WAF. In addition. the CIB does not seem to produce large, blocky coke (as was the case in some WAF tests) but does tend to produce large clinkers (fused ash) for some of the lower AST coals.

The selected 1.8 MMBtu/hr firing rate was found to produce intense combustion conditions and acnieve the vendor-stated $65 \%$ overall thermal efficiency. A factor in firing rate selection was the baghouse iniet temperature which must be maintained below $425^{\circ} \mathrm{F}$ to prevent damage to the Nomex bags. It should be noted that baghouses are not used for units of this size in actual installations: typically, particulate control is achieved with (cheaper. simpier. lower maintenance) cyclones. Of course, as developments in higher temperature filtration media (e.g., ceramic) proceed, baghouse-type filters could be developed for smail 
commercial stokers. At present, the PETC system relies on a nitrogen/water spray nozzle humidification system, located about $10 \mathrm{ft}$ upstream of the baghouse inlet, which can provide a maximum of $180,000 \mathrm{Btu} / \mathrm{hr}$ of cooling which could reduce the flue gas temperature by approximately $250 \mathrm{~F}^{\circ}$. This translates into a maximum boiler exit temperature of about $750^{\circ} \mathrm{F}$ (accounting for other pipe heat losses between boiler exit and baghouse inlet) to maintain a $400^{\circ} \mathrm{F}$ inlet baghouse temperature and allow for normal fluctuations in CIB burning rate.

Another key consideration in selecting the firing rate was firebox ash accumulation. While the CIB has a peak firing rate approximately 14 times that of the WAF, the CIB design does not appear to be as accommodating with respect to ash buildup capacity. For example, the CIB firebox floor area is only about 5 times that found in the WAF; in considering the area surrounding the retort, the CIB is only 4 times greater than the WAF. One possible reason for this apparent size discrepancy is that an actual CIB installation would likely have a boiler operator to perform periodic ash cleanout while a residentially-sized unit (e.g., WAF) may be designed for less frequent ash removal by the homeowner.

As was the case with the WAF, units in the CIB's size range are similarly meant to cycle (on/off) in order to match variable heating demands at the boiler site. For this reason, continuous operation at reduced load (approximately 70\%) seemed appropriate as was found previously from materials considerations in the WAF.

During CIB testing, the baghouse was pulsed periodically (usually several times per test) when the overall baghouse pressure drop exceeded 5 in $\mathrm{H}_{2} \mathrm{O}$. This translates into a 3 in $\mathrm{H}_{2} \mathrm{O}$ drop across the filter cake given the normal baseline 2 in $\mathrm{H}_{2} \mathrm{O}$ drop across the baghouse at typical flow rates. Because of periodic pulsing and size considerations, the CIB is operated at higher drafts than the WAF. Typically, CIB testing was performed at $0.15-0.40$ in $\mathrm{H}_{2} \mathrm{O}$ draft to prevent flue gas seepage from the boiler front panels during pulsing periods and burning rate fluctuations. This level of draft produced measured air in-leakages of about 80 to $200 \mathrm{lb} / \mathrm{hr}$ for the 0.15 to 0.40 in $\mathrm{H}_{2} \mathrm{O}$ draft range, respectively, which represents only about $3-8 \%$ of the flue gas flow rate as determined from the sum of the combustion air, overfire air, and fuel (gas equivalent) burning rate. In CIB cold flow tests at (nearly) zero draft, gas flow agreement was generally $98 \%$ or better, upon comparing the boiler exit (venturi) flow to the sum of the combustion and overfire air flow orifice measurements. For this reason. it is felt that the small air in-leakage has minimal influence on the most important $\mathrm{CIB}$ experimental findings. 


\section{FEEDSCREW DEGRADATION RESULTS}

Table : presents the WAF feedscrew test results. Samples were sieved at the following sizes: : inch, $3 / 4$ inch, $1 / 2$ inch, $1 / 4$ inch, 8 mesh, 28 mesh, and pan. To simplify the resuits. size distributions are grouped into the most important fractions which are taken at the $1 ;-$ inch and 28 mesh sizes.

Table 3 : Size Distributions after WAF Feedscrew Test

\begin{tabular}{|lccc|}
\hline \multicolumn{1}{|c}{ FUEL } & $\begin{array}{c}\text { Wt\% } \\
+1 / 4 \text { inch }\end{array}$ & $\begin{array}{c}\text { Wt\% } \\
+28 \text { mesh }\end{array}$ & $\begin{array}{c}\text { Wt\% } \\
-28 \text { mesh }\end{array}$ \\
\hline Pgh/RDF5 Extrudate & 76 & 15 & 8 \\
Pgh/RDF2 Extrudate & 81 & 11 & 8 \\
Pcy (5 cc) Briquette & 67 & 22 & 11 \\
Pcy/Coke Briquette & 40 & 25 & 35 \\
Pcy/Lime Briquette & 78 & 11 & 10 \\
PETC Stoker Coal & $62-86$ & $11-29$ & $1-9$ \\
PETC Briquette - All & $6-78$ & $11-41$ & $10-55$ \\
- Most & $40-66$ & $17-31$ & $16-29$ \\
\hline \hline
\end{tabular}

The Pפh/RDF2 and Pgh/RDF5 extrudates were excellent as very little size degradation was observed. Size distributions of the two extrudates were comparable to those observed with typical U.S. stoker coals. These extrudates were superior to the PETC coal-based briquettes owing to the combination of their slightly larger size and apparently (no measurements provided) greater compressive strengths; compressive strengths for the PETC coal-based briquemes were in the $14-28 \mathrm{lb}$ range. These factors also likely explain the degradation resistance of the large $5 \mathrm{cc}$ Pocahontas briquette.

In contrast to the extruded coal/RDF fuels, the Pocahontas/coke briquette underwent considerably more breakage, resulting in a size distribution on the lower side of what has typically been observed with briquetted fuels tested at PETC. However, the size distriburions of briquetted fuels after feedscrew tests have varied widely as shown in Table 3. Incied, for one briquette (Pocahontas/hydrated lime), excellent structural integrity was observed. This suggests that some "fine tuning" of the briquetting process can achieve dramanc results, particularly when considering the closeness in crushed coal particle size (14 mesh with $20 \%$ less 100 mesh), binder addition (3-4 wt \%), and also sorbent dosage (0-11 wt\%) used in the PETC briquetted coal-based fuels. 
The Pittsburgh coal/paper extrudates were excellent in WAF feedscrew tests. Both the asreceived and dried material fed with less than $10 \%$ breakage. This was determined from PETC hand screening at $1 / 8$ inch which was performed (in lieu of sending the samples to an outside contractor) because of the limited quantity of fuel and the desire to conduct additional WAF tests.

Screening of the CIB feedscrew samples (by Warner Labs) has not been completed as yet. However. a few observations are noteworthy. The CIB appears to be significantly more destructive of the briquetted fuels which entailed 1,5 , and $7 \mathrm{cc}$ briquette sizes as compared to the WAF. The main reason for the increased crushing is the larger force exerted at the screw inlet when the feed hopper is filled. This can be alleviated somewhat by feeding the fuels at a lower hopper inventory. In a few crude tests, breakage was reduced from about $90 \%$ to about $45 \%$ by maintaining low hopper inventory.

\section{COMBLSTION/EMISSIONS RESULTS}

Table 4 summarizes the combustion/emissions results in the WAF and CIB facilities. Emissions data were calculated based on results obtained during the last 4-5 hours of each test, where operations were the most stable. In the WAF, considerable difficulty was encountered in firing the combustion/emissions screening tests for the Pittsburgh stoker, Pocahontas \#3 stoker, Pocahontas $5 \mathrm{cc}$ briquette, and Pocahontas/Coke $1 \mathrm{cc}$ briquette. These fuels resulted in highly irregular fuel beds which produced poor combustion conditions as indicated by the low carbon conversions (64-82\%) in Table 4. Air/fuel conditions were adjusted during the test to try to optimize combustion; however, success was limited. In general, these caking fuels seem to burn better at higher firing rates and total air flow rates, although rurnace temperature constraints can become a factor here. Some success was found (in the Pocahontas series) by lowering the combustion air and increasing overfire air to help burn tall coke trees. For this reason, the Pocahontas stoker and sorbentless $5 \mathrm{cc}$ briquette were acually conducted at sub-stoichiometric conditions in terms of retort combustion air (overfire air not included) as shown in Table 4. Particularly troublesome was the Pocahoneas/Coke $1 \mathrm{cc}$ briquette which produced considerable quantities of fines which effectively limit air flow rates due to sparkler formation.

In sharp contrast, good combustion in the WAF was achieved for the RDF- (Pittsburgh coal), paper- (Pittsburgh), and lime- (Pocahontas \#3) containing agglomerated fuels which exhibited carbon conversions in the $95-98 \%$ range. These fuels burned with virtually no adjustment in air/fuel flow during the tests. The principal reason for the improved combustion was a sharp reduction in coke tree formation. In contrast to the above fuels which produced large, blocky coke, these fuel beds consisted of very porous and brittle coke which naturally fractured and burned. PETC's results with other parent stoker coals which underwent considerably less coking when agglomerated in the presence of even low (3-5 wt\%) dosages of sorbent are described in a recent paper which is enclosed. 
Table 2 : WAF/CIB Screening Results of CONSOL Stoker Coals and Agglomerated Fuels

\begin{tabular}{|c|c|c|c|c|c|c|c|c|c|c|c|}
\hline \multirow[b]{2}{*}{ IULI IYILL } & \multicolumn{5}{|c|}{ Werm-Air Furnace Tests } & \multicolumn{4}{|c|}{ Warm-Air Furnace Tests } & \multicolumn{2}{|c|}{ Cust-Iron Boilur Tusits } \\
\hline & $\begin{array}{c}\text { Pill } \\
\text { STOKER }\end{array}$ & $\begin{array}{l}\text { PGII } \\
\text { EXT } \\
\text { PAPEA }\end{array}$ & $\begin{array}{l}\text { I'GIl } \\
\text { EXT-dry } \\
\text { PAPER }\end{array}$ & $\begin{array}{l}\text { PGII } \\
\text { EXT } \\
\text { RDF } 2\end{array}$ & $\begin{array}{l}\text { PGill } \\
\text { EXT } \\
\text { RDF } 5\end{array}$ & $\begin{array}{c}\text { PCY } \\
\text { STOKER }\end{array}$ & $\begin{array}{c}\mu C Y \\
\text { BRQ } \\
C a / S=0\end{array}$ & $\begin{array}{l}\text { PCY } \\
\text { BRQ } \\
\text { COKE }\end{array}$ & $\begin{array}{c}\text { HCY } \\
\text { BRO } \\
\mathrm{Ca} / \mathrm{S}=3\end{array}$ & $\begin{array}{c}\mu \mathrm{CY} \\
\mathrm{BRQ} \\
\mathrm{Ca} / \mathrm{S}=0\end{array}$ & $\begin{array}{l}P C: Y \\
B R Q \\
C a / S \\
=3\end{array}$ \\
\hline $\begin{array}{l}\text { FUEL FEED RATE (LB/HR) } \\
\text { FIRING RATE IN } 1000 \text { BTU/HR }\end{array}$ & $\begin{array}{r}13.2 \\
180 \\
\end{array}$ & $\begin{array}{r}12.6 \\
128 \\
\end{array}$ & $\begin{array}{r}12.7 \\
158 \\
\end{array}$ & $\begin{array}{r}14.6 \\
157 \\
\end{array}$ & $\begin{array}{r}15.1 \\
160 \\
\end{array}$ & $\begin{array}{r}16.0 \\
234 \\
\end{array}$ & $\begin{array}{r}16.9 \\
240 \\
\end{array}$ & $\begin{array}{r}16.9 \\
227 \\
\end{array}$ & $\begin{array}{r}11.4 \\
151 \\
\end{array}$ & $\begin{array}{r}121 \\
1750\end{array}$ & $\begin{array}{r}152 \\
2050\end{array}$ \\
\hline $\begin{array}{l}\text { COMBUSTION AIR (LB/HR) } \\
\text { OVERFIRE AIR (LB/HR) } \\
\text { TOTAL AIR (LB/HR) }\end{array}$ & $\begin{array}{r}201 \\
80 \\
281 \\
\end{array}$ & $\begin{array}{r}196 \\
60 \\
256 \\
\end{array}$ & $\begin{array}{r}205 \\
69 \\
274 \\
\end{array}$ & $\begin{array}{r}184 \\
53 \\
237\end{array}$ & $\begin{array}{r}183 \\
50 \\
233 \\
\end{array}$ & $\begin{array}{l}164 \\
116 \\
280\end{array}$ & $\begin{array}{r}168 \\
94 \\
262\end{array}$ & $\begin{array}{l}190 \\
113 \\
303\end{array}$ & $\begin{array}{r}173 \\
51 \\
224\end{array}$ & $\begin{array}{r}1950 \\
150 \\
2100\end{array}$ & $\begin{array}{r}2100 \\
200 \\
2300\end{array}$ \\
\hline $\begin{array}{l}\text { \% EXCESS RETORT COMBUSTION AIR } \\
\% \text { EXCESS TOTAL AIR } \\
\% \text { OVERFIRE TOTAL AIR }\end{array}$ & $\begin{array}{r}53 \\
114 \\
28 \\
\end{array}$ & $\begin{array}{r}95 \\
154 \\
29 \\
\end{array}$ & $\begin{array}{r}64 \\
119 \\
23 \\
\end{array}$ & $\begin{array}{l}54 \\
98 \\
22 \\
\end{array}$ & $\begin{array}{l}51 \\
92 \\
21\end{array}$ & $\begin{array}{l}-7 \\
58 \\
41 \\
\end{array}$ & $\begin{array}{r}-10 \\
40 \\
36 \\
\end{array}$ & $\begin{array}{r}4 \\
66 \\
37 \\
\end{array}$ & $\begin{array}{l}47 \\
91 \\
23\end{array}$ & $\begin{array}{r}45 \\
58 \\
7\end{array}$ & $\begin{array}{r}35 \\
47 \\
9\end{array}$ \\
\hline FLUE GAS MOISTURE (mol\%) & 3.0 & 3.7 & 3.1 & 5.6 & 4.6 & 4.0 & 3.5 & 3.1 & 3.2 & 4.8 & 4.2 \\
\hline $\begin{array}{l}\text { AVERAGE FLUE GAS (dry) } \\
\mathrm{CO}_{2}(\%) \\
\mathrm{O}_{2}(\%) \cdot \mathrm{ACTUAL} \\
\mathrm{CO}(\mathrm{PPM}) \\
\mathrm{SO}_{2} \text { (PPM) } \\
\mathrm{NO}_{\times} \text {(PPM) } \\
\mathrm{THC}(\mathrm{PPM}) \\
\end{array}$ & $\begin{array}{r}6.6 \\
13.5 \\
1013 \\
659 \\
155 \\
42 \\
\end{array}$ & $\begin{array}{r}6.9 \\
13.1 \\
1027 \\
476 \\
158 \\
13 \\
\end{array}$ & $\begin{array}{r}7.6 \\
12.05 \\
607 \\
502 \\
148 \\
8.3 \\
\end{array}$ & $\begin{array}{r}9.8 \\
9.8 \\
115 \\
575 \\
120 \\
1.3 \\
\end{array}$ & $\begin{array}{r}8.1 \\
11.4 \\
178 \\
376 \\
117 \\
3.0 \\
\end{array}$ & $\begin{array}{r}9.2 \\
10.5 \\
1185 \\
361 \\
112 \\
4.1 \\
\end{array}$ & $\begin{array}{r}12.5 \\
7.2 \\
435 \\
561 \\
115 \\
9.9 \\
\end{array}$ & $\begin{array}{r}7.3 \\
12.7 \\
851 \\
189 \\
128 \\
4.4 \\
\end{array}$ & $\begin{array}{r}9.1 \\
10.0 \\
162 \\
171 \\
68 \\
1.0\end{array}$ & $\begin{array}{r}10.9 \\
9.2 \\
42 \\
392 \\
187 \\
2.1\end{array}$ & $\begin{array}{r}11.1 \\
8.1 \\
68 \\
348 \\
142 \\
4.3\end{array}$ \\
\hline $\begin{array}{l}\text { AVERAGE FLUE GAS (dry) } \\
\mathrm{CO},(\%) \\
\mathrm{O}_{2}(\%)-\text { COKRECTED TO } 0 \% \\
\mathrm{CO} \text { (PPM) } \\
\mathrm{SO}_{2} \text { (PPM) } \\
\mathrm{NO}_{4} \text { (PPM) } \\
\text { THC (PPM) }\end{array}$ & $\begin{array}{r}18.5 \\
0.0 \\
2825 \\
1839 \\
432 \\
118 \\
\end{array}$ & $\begin{array}{r}18.3 \\
0.0 \\
2731 \\
1265 \\
419 \\
36 \\
\end{array}$ & $\begin{array}{r}17.9 \\
0.0 \\
1423 \\
1177 \\
346 \\
20 \\
\end{array}$ & $\begin{array}{r}18.4 \\
0.0 \\
216 \\
1078 \\
225 \\
2.4 \\
\end{array}$ & $\begin{array}{r}17.7 \\
0.0 \\
389 \\
823 \\
256 \\
6.6 \\
\end{array}$ & $\begin{array}{r}18.4 \\
0.0 \\
2370 \\
722 \\
224 \\
82 \\
\end{array}$ & $\begin{array}{r}18.8 \\
0.0 \\
655 \\
853 \\
172 \\
15 \\
\end{array}$ & $\begin{array}{r}18.5 \\
0.0 \\
2153 \\
478 \\
324 \\
11 \\
\end{array}$ & $\begin{array}{r}17.4 \\
0.0 \\
309 \\
326 \\
130 \\
1.9 \\
\end{array}$ & $\begin{array}{r}19.4 \\
0.0 \\
74 \\
697 \\
333 \\
3.7 \\
\end{array}$ & $\begin{array}{r}18.2 \\
0.0 \\
111 \\
568 \\
232 \\
7.0\end{array}$ \\
\hline $\begin{array}{l}\text { LB/MMBTU (FUEI.) } \\
\mathrm{CO} \\
\mathrm{SO}_{2} \\
\mathrm{NO}_{2} \text { as } \mathrm{NO}_{2} \\
\mathrm{THC}\end{array}$ & $\begin{array}{l}2.36 \\
2.71 \\
0.54 \\
0.055\end{array}$ & $\begin{array}{l}1.94 \\
2.01 \\
0.49 \\
0.015\end{array}$ & $\begin{array}{l}0.99 \\
1.84 \\
0.39 \\
0.0077\end{array}$ & $\begin{array}{l}0.35 \\
1.88 \\
0.30 \\
0.0031\end{array}$ & $\begin{array}{l}0.48 \\
1.12 \\
0.30 \\
0.0041\end{array}$ & $\begin{array}{l}1.50 \\
0.96 \\
0.22 \\
0.0047\end{array}$ & $\begin{array}{l}0.44 \\
1.25 \\
0.20 \\
0.0060\end{array}$ & $\begin{array}{l}2.12 \\
0.50 \\
0.26 \\
0.0020\end{array}$ & $\begin{array}{l}0.22 \\
0.55 \\
0.16 \\
0.0008\end{array}$ & $\begin{array}{l}0.055 \\
1.18 \\
0.40 \\
0.0016\end{array}$ & $\begin{array}{l}0.083 \\
0.97 \\
0.28 \\
0.003 \\
0\end{array}$ \\
\hline CARBON CONVERSION $(\%)$ & 80 & 98 & 96 & 97 & 98 & 70 & 82 & 64 & 97 & 95 & 97 \\
\hline FLYASH (GR/SCF) & NA & 0.020 & 0.030 & 0.036 & 0.030 & 0.022 & NA & 0.115 & 0.018 & 0.020 & 0.072 \\
\hline
\end{tabular}


During testing, it has become clear that the CIB facility is much better suited for the combustion of caking fuels. This is illustrated in Table 4 upon comparing the sorbentless vs. lime-containing Pocahontas briquette results. Clearly, the marked improvement found in the WAF operations was not nearly as distinguishable during operations in the CIB. Available literature indicates that the underfeed stoker design is critical for successful combuscion of caking coals, as evidenced by the widely variant accounts of caking coal compatibiiity with underfeed stokers in the abundant pre-1960 studies. One reason for this effect may be that the CIB fuel bed appears to be about 100-300 $\mathrm{F}^{\circ}$ hotter than the WAF which typically exhibited furnace temperatures in the $2000-2700{ }^{\circ} \mathrm{F}$ range, with the more common average values in the $2100-2400{ }^{\circ} \mathrm{F}$ range. The higher CIB bed temperatures probably accounts for the lower (15-20\%) $\mathrm{SO}_{2}$ capture of the lime-containing briquettes relative to the $40 \%$ removals observed at $\mathrm{Ca} / \mathrm{S}=3$ for briquetted fuels in the WAF.

In comparing $\mathrm{lb} / \mathrm{MMBtu} \mathrm{SO}_{2}$ emissions (Table 4) with predicted fuel analyses (Tables 1 and 2 ), it appears that approximately $20 \%$ sulfur capture has occurred for the Pgh/RDF2 fuel and about $40 \%$ removal for the Pgh/RDF5 fuel. PETC performed elemental ash analyses on these samples with the following results

$\begin{array}{lcc} & \begin{array}{c}\text { Pgh } \\ \text { RDF5 }\end{array} & \begin{array}{c}\text { Pgh } \\ \text { RDF2 }\end{array} \\ & & \\ \mathrm{SiO}_{2} & 29.48 & 27.03 \\ \mathrm{Al}_{2} \mathrm{O}_{3} & 16.73 & 15.47 \\ \mathrm{Fe}_{3} \mathrm{O}_{3} & 7.04 & 7.52 \\ \mathrm{TiO}_{3} & 0.97 & 1.03 \\ \mathrm{P}_{2} \mathrm{O}_{5} & 0.00 & 0.00 \\ \mathrm{CaO} & 16.84 & 19.52 \\ \mathrm{MgO} & 1.20 & 1.07 \\ \mathrm{Na}_{5} \mathrm{O} & 2.34 & 1.63 \\ \mathrm{~K}_{2} \mathrm{O} & 1.16 & 1.14 \\ \mathrm{SO}_{3} & 13.26 & 16.93\end{array}$

These results translate into a $\mathrm{Ca} / \mathrm{S}$ mole ratio of 1.5 for the $\mathrm{Pgh} / \mathrm{RDF} 5$ briquette and 1.3 for Pgh/RDF2 briquette. The elevated calcium content of these fuels could explain the observed sulfur capure, although the $40 \%$ sulfur removal for the Pgh/RDF5 seems high given this level of calcium.

$\mathrm{NO}_{\mathrm{x}}$ emissions were in the $0.16-0.54 \mathrm{lb} / \mathrm{MMBtu}$ range during all tests. This corresponds to about $5-15 \%$ of the fuel nitrogen equivalent. given the standard assumption that thermal $\mathrm{NO}_{\mathrm{r}}$ is minimal under stoker combustion conditions. Other emissions (THC, particulate) were in the same range as other tests in the WAF. One interesting note is that the $\mathrm{CO}$ emissions were the lowest in the $\mathrm{CIB}$ tests, probably reflecting the higher bed temperature in the $\mathrm{CIB}$ as compared to the WAF. 


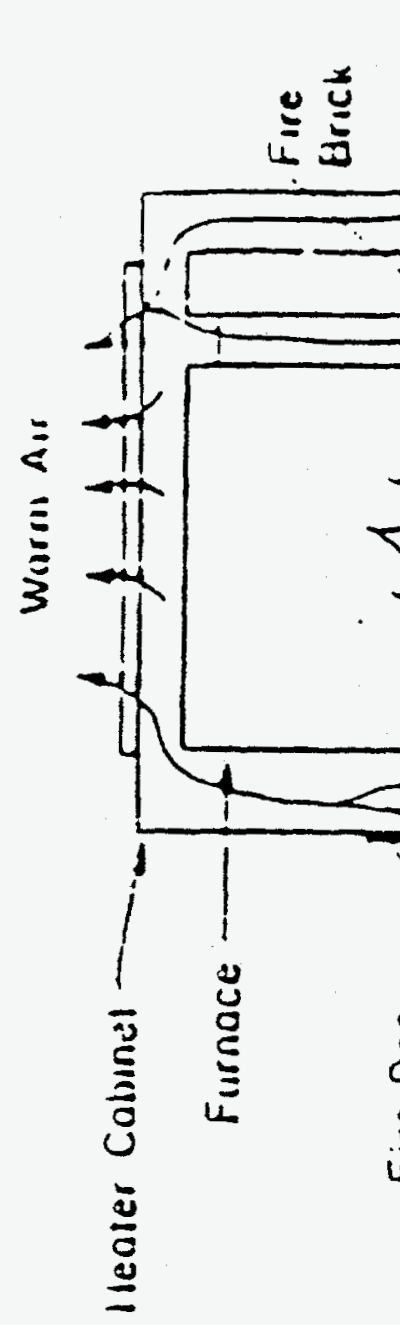

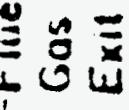

$\bar{q}$

0

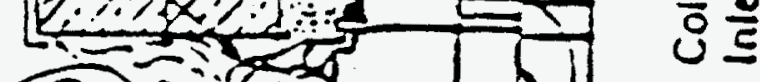

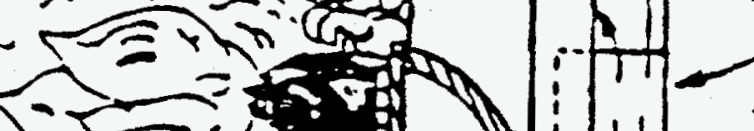

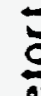

$\frac{5}{0}$

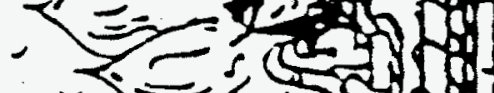

\begin{tabular}{|c|c|c|}
\hline & 1 & 1
\end{tabular}

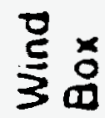

胥

2

$\frac{2}{2}$

a1 $=15$

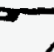

100

$\stackrel{\circ}{\circ}$

तi:

4 늠
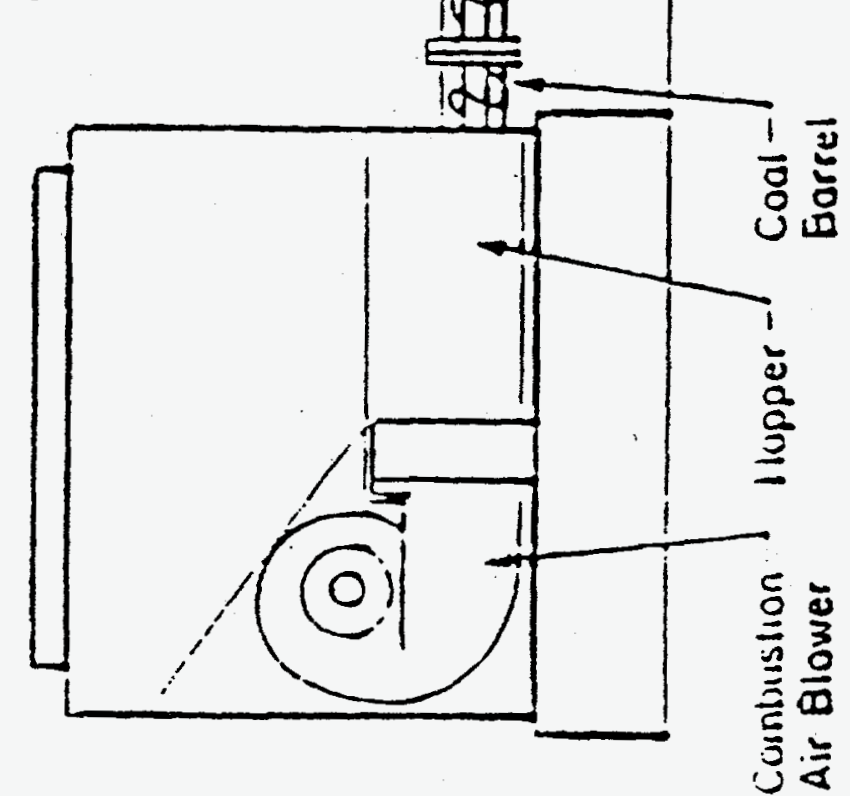

ธั

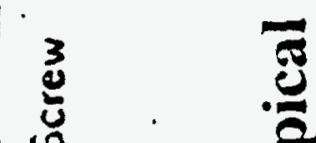

8

2

$\sigma$

$+\frac{1}{\circ}$

3

है 


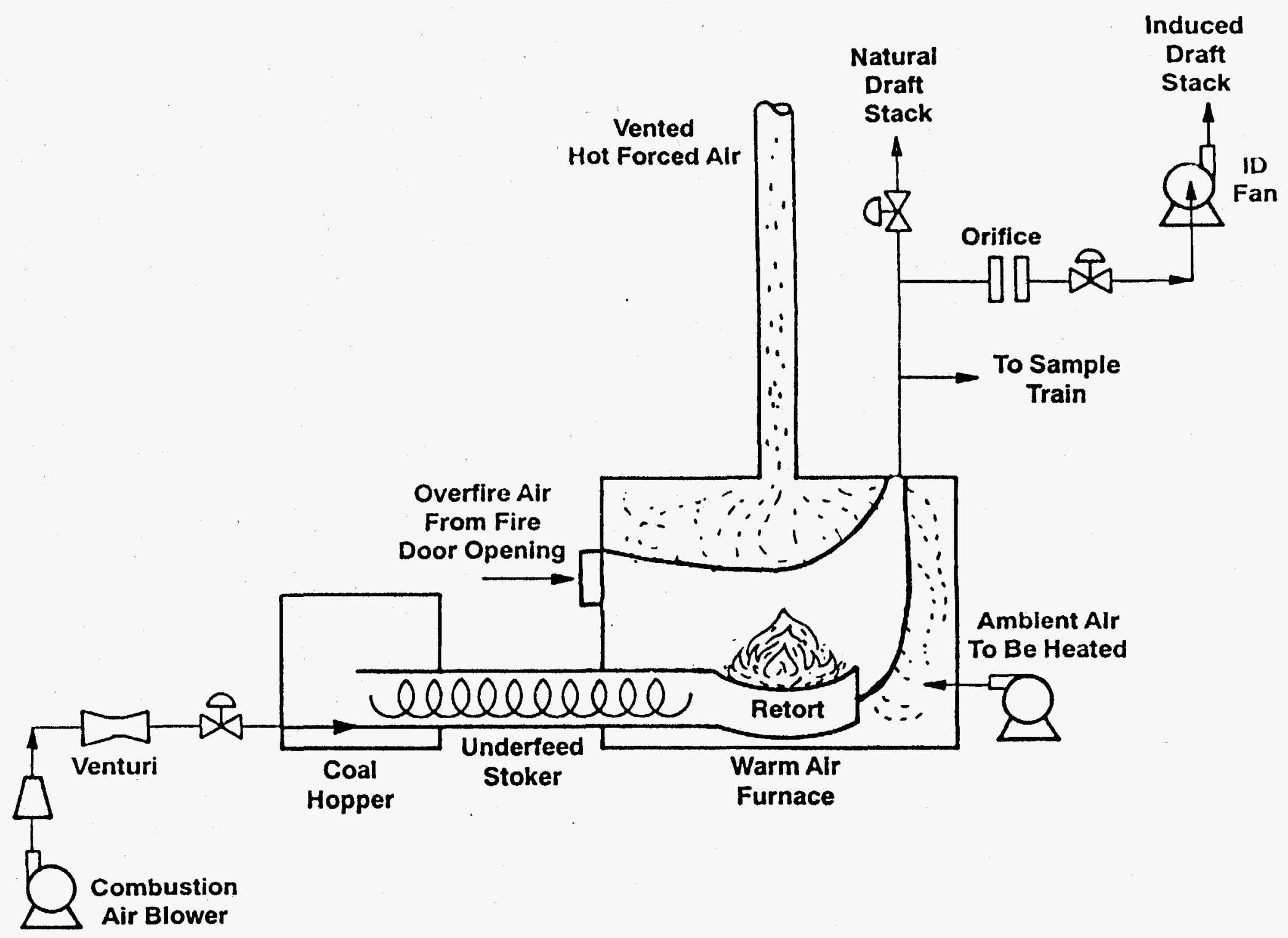

Figure 2 : Flow Schematic of Warm-Air Furnace Test Facility 


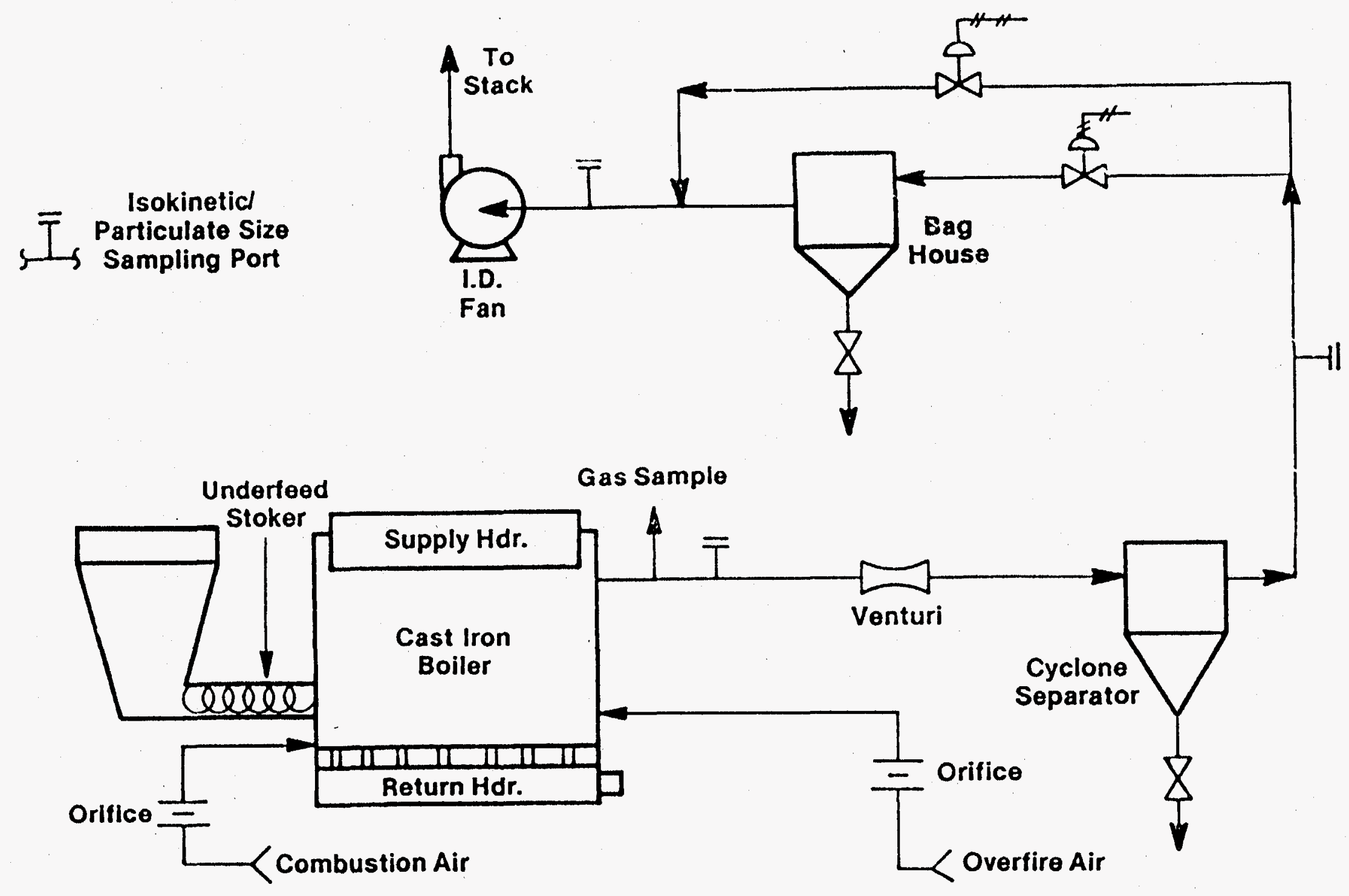

Figure 3 : Flow Schematic of Cast-Iron Boiler Test Facility 


\title{
Emissions Evaluation of Eriquetted Coai/Sorbent Fueis
}

\author{
Ifark C. Freeman, Fenry W. Pennine. James I. Joubert \\ Pitusburgh Exergy Tecinology Center \\ U.S. Department or Energy, Pittsburgn, P.A 15236 \\ Paul A. Vore and Linda Kuzior \\ Gilber/Commonweaith. Inc.. Library, PA :s129
}

\begin{abstract}
The in-nouse tlue gas cleanup program at the Pittsburgn Energy Technology Center has conducted studies to evaluate novel coal/sorbent briquetted fuels aimed at meeting stringent emissions standaros in conventional coal-fired small-scaie comoustors. Results to date have been encouraging, as typical $\mathrm{SO}_{2}$ removals of approximately $40 \%$ for briquetted coal/sorbent fuels were observed at caicium-to-sulfur molar ratios of about three to one. For one fuel. $\mathrm{SO}_{2}$ removals exceeded $\mathbf{5 0 \% \text { . }}$ Marked improvements in combustion characteristics were also observed for the briquetted fueis containing sorbent. even at dosages as low as $3-5$ wit. for five parent coals. Other signiricant tindings are presented along with an overview of the experimentai facilities.
\end{abstract}

\section{INTRODUCTION}

The Pirtsburgh Energy Technology Center (PETC) of the U.S. Department of Energy has supported the deveiopment of novei coal-based fueis and combustors that could displace natural gas and fuel ji in smail-scale (< $100 \mathrm{MMBtu} / \mathrm{hr}$ ) heating systems. In 1988, the PETC Flue Gas Cleanup Trogram issued a solicitation entitled "Enissions Control for Smail-Scale Combustors" in winich imissions of $0.4 \mathrm{lb} \mathrm{SO}_{2} \mathrm{MMBtu}, 0.2 \mathrm{lb} \mathrm{NO} / \mathrm{MMBtu}$ and $0.02 \mathrm{lb}$ paruculate/MMBtu were targeted for new combustors while industriai retront $(10-100 \mathrm{MMBu}$ hr) targets were set somewhat higher at $1.2 \mathrm{~b} \mathrm{SO}_{2} \mathrm{MMBtu}, 0.6 \mathrm{lb} \mathrm{NO}_{\mathrm{x}} \mathrm{MMBtu}$. and $0.03 \mathrm{lb}$ particuiate $\mathrm{MMBtu}$ [1].

The current in-house PETC research effort seeks to characterize the emissions of traditional stoker coals and novel coal/sorbent fuels in actual smail-scale furnaces under realistic operating conditions. These cinaracterizations are needed to assess present emissions and potential emissions controis with stoker technology. Severai motivations are behind the evaluation of reconstituted coal fueis for stoker-rired combustors. At present. a signiricant opportunity exists for agglomeration or by-product fines (14-28 mesin) from conventional coal-cleaning operanons. This opportunity is magnined in advanced coal cleaning processes, which produce much finer $(-325 \mathrm{mesh})$ material. While coai reconsturution effors are typically aimed as uniity appitcations, the smail-scaie stoker market couid provide early penetration potential for such fueis based on the more favorable economics associated with the cost premiums (approximately $\$ 2-7 /$ ton) charged for stoker-sized versus utility-sized coais [2]. Finaily, the inclusion of small amounts of soribent in the reconstituted fuels offers the potental to lower $\mathrm{SO}_{2}$ emissions. To achieve the $0.4 \mathrm{lb} \mathrm{SO}_{2} \mathrm{MLMBtu}$ levei for a $13,000 \mathrm{Btw} / \mathrm{b}$ coai. SO, removais need to be in the 48 to $78 \%$ range tor coal suifur contents of $0.5 \%$ to $1.0 \%$ ' respecriveiy. These leveis of $\mathrm{SO}_{2}$ caprure mignt ce acnievaple using coai/sordent rieis and commercial stoker technology. 


\section{EXPERIMENTAL : Warm-Air Fumace Tus: Fachiaw}

A cession was made to conduct screenings with actuai stoker furnaces rather than building a batch or sem:-iontinuous simulator furnace. To minimize coal/sorbent fuel fabrication costs, underieed stoke ants were selected based on their commerciaj avariability at low themai inputs. It was felt that -2 most important combustion/emissions experimental resuits would be transierrable to the rave:- $=$-grate and spreacer stokers more commoniy iound in large commercial/industrial boilers. This isumption was based on the bulk of the existing stoker literarure.

A 2 2.:00 Btu/hr (inpur) residential warm-air tumace (WAF) was obtained from the Will-Burt Company to perform the emissions evaluations. Under continuous operation, the WAF requires only $: 20 \mathrm{lb}$ of fuel per test day. The WAF was modified to provide accurate data under realisric fumace operation. For exampie, the built-in combustion air blower was replaced with a more powe:-:i blower to permit installation of a venturi and pneumatically controlled buttertly vaive. Similariy, an induced drait fan, orifice, and control system were installed in the flue gas stack A calibrated rotary meter was used to standardize the orifice and venturi meters. Overrire air is reguizizod by adjusting fireoox door slat-openings and the fumace dratt. Figure I presents an overail How sc:ematic of the WAF test faciilty. Other WAF feanures include 1) variabie-speed auger motor drive $: 3$ adjust feed rates, 2) nitrogen purge for fire quenching, and 3) sight port for visual ooserracons, video recording, and pyrometer readings. An existing nanural draft stack was not unilizeo in this study. Further details on the WAF have been given eisewhere [3].

Beci-man Model 865 nondispersive infrared (IR) anaiyzers are used to track carbon dioxide (0-20\%) and ci=oon monoxide $(0-5000 \mathrm{ppm})$ emissions. A Beckman Model $880 \mathrm{R}$ analyzer provides neasurement of $0-500 \mathrm{ppm} \mathrm{CO}$ which allows more precise continuous monitoring without changing anaivar ranges. This capabiiity permits accurate measurement of $\mathrm{CO}$ emissions that can exceed an orcer of magnitude during a test. In similar fasnion. two total hydrocarion (THC) analyzers are empicyed. A Beckman Model 400A provices coverage in the range of $0.10 \mathrm{ppm}$ during continuous screesing tests while a Beckman Model 400 allows $0-100$ ppm monitoring. A Thermo Elecron Mode: :O chemiluminescent NO, analyzer $(0-1000 \mathrm{ppm})$ is used as weil as a Beckman Model $755 \mathrm{~A}$ paramagnetic oxygen analyzer $(0-25 \%)$. $\mathrm{SO}_{2}$ is monitored with Beckman Model 865 (0-2000 ppm), a Horisa PIR-2000 (0-1000 ppm), and a moisture-compensated Horioa VIA-200 (0-200 ppm) nonoispersive infrared analyzers. A Kaye Corporation data logger transmits gas compositions and other readings (e.g., temperatures, pressure drops) to a DEC PDP $11 / 70$ for data storage every 24 seconos. Fortran programs calculate the reievant engineering quanticies - for example, $\mathrm{lb} / \mathrm{hr}$ of $\mathrm{SO}_{3}$, Btwint of flue gas sensible heat. etc. - which are then integrated over the length of the test to provice absolute quantities for material and energy baiances. Such emissions integrations have not been reforted previousiy in the literature.

A ince gas sample was continually withdrawn through a Mott Metallurgical 2-in diameter cylincicai, sintered stainless steel filter ( 5 microns) for particulate removal prior to sample moisture knockout in a $32^{\circ} \mathrm{F}$ ice bath. Vapor-liquid equilibrium calculations $\left(\mathrm{SO}_{2} / \mathrm{H}_{2} \mathrm{O}\right.$ ) and ion chromarography measurements of the condensate reveajed an acceptably low effect on $\mathrm{SO}_{2}$ during moisnre knockout. A Perma Pure drier iunher reciuces residual sample moisture which would otherwze increase readings signiñcantly at low ieveis $i<100 \mathrm{ppm}$ l of $\mathrm{SO}_{2}$. \& $32^{\circ} \mathrm{F}$ dewoint couid produce an interference of about $6 \mathrm{ppm} \mathrm{SO}$, based on the typicaily accepted intertierence ratio (100 ppm $\because: 0=1$ ppm $\mathrm{SO}_{2}$ ) with intrared $\mathrm{SO}_{2}$ anaiyzers. 
2arent: Cis. Bricuerte Presaration. and WAF Szerazon

Tabie : zresents the anaiyses for the coais that inciude Hazard $\$ 4$ (Kentucky), Brookville (Pennsyi*ania), Twin Branch (West Virginia), Blue Gem (Kentuciy), and Pocahontas \#3 (Virginia). The coais jiffer in free-swelling index, ash soitening temperanre, rank. and chemical content The Blue $G=x$ coal was procured in both a raw $14 \%$ asn) and cleaned ( $1 \% 0$ ash) stoker form to simulate the crocxets from advanced coal cleaning processes: thus, these coass are reterred to as Blue Gem Medium $\therefore$ sh and Blue Gem Low Ash, respecriveiy.

Coaisorcent briquetted fuels ( $3 / 4 "$ x $3 / 8 "$ x $5 / 16^{\prime \prime}$ ) were prepared with a Ferrotech Model WP-10 Bricueter using a starch-based BREWEX (RDE Incorporated) binder. The selected sorbents for the inidai screenings inciuded hydrated lime (Mercer Lime Company), a low-magnesium dolomitic limestone (National Lime and Stone Co.), and a high-purity calcitic limestone (Dravo Corporation). Eaci batca of briquettes was formed from 14 mesh crusined coai to simulate conventionaily cleaned tines. aitrough it is recognized that conventionally cleaned fines couid differ in other characteristics. A reateo high-speed mixer was used to blend crusned coal, binder, and sorbent; in several instances. water $(0.5-2.0 \mathrm{wt} \%)$ was added to the mixture to minimize dustiness. Table 2 presents briquente compositions, laboratory strength determinations, and heating values. Briqueting procesciec smoothly for the heated $\left(155^{\circ} \mathrm{F}\right.$ to $\left.185^{\circ} \mathrm{F}\right)$ blends, resulting in satisfactory compressive (typicaily over $18 \mathrm{lbs}$ ) and six-foot drop/shatter (typicaily 90\% pius 1/4") strengths. Because of the low sorcent and binder dosages, the briquened fuel hearing vaiues were acceptable (over $89 \%$ ) -eianve : 2 the parent stoker coals. The CaS ratio for the fuels was based on the caicium content of tise sccsent and on the suifur content of the coal.

Screening tests were conducted in the WAF under contnuous firing based on the cesire to mimic the conditons found in large commercial and industrial boilers. Typically, a 1-hr feedscrew test ias țericmed to reveai fuel grindability and determine auger feed (rpm) setrings needed to actieve in aperoximate constant firing rate of $150.000 \mathrm{Bru} / \mathrm{hr}$ (input). This point became important when Eariier studies reveaied that briquettes fed as mucn as $50 \%$ faster than the stoker coals. Figure 2 compares ine average size distributions for the fed bricuetted fueis and fed stoker coais along with zaw stcier coals. Briquetted fueis were prescreened to remove fines prior to feedscrew and emissions screening tests.

After the teedscrew test. fresh fuel $(2-4 \mathrm{lb})$ and wood kinaling were piaced over the retor. After ligning. zombustion air was initiated for 10-15 minutes to establish the fire before initiation of coal ieed. Tyically, a warmup period was conducted to establish the proper amount of combustion and overrire ar. Initial conditions were set at $50 \%$ excess comoustion air plus an additionai $50 \mathrm{lb} / \mathrm{hr}$ of overite air and then altered, if necessary, to acnieve more optimum comoustion ior the suoseouent formal 6-hour test period. During this period. air flows were generally constant and oniy occsional adjustments were made to ensure a good test burn. Bed temperatures were obtained with a Cojintec Instruments, Inc. Ratio-Scope Mocel III dual-wavelength intrared pyrometer.

At the erd of each test. combustion air and fuel feed were tumed off: the firebox was allowed to cooi for 1 minutes betore tlooding with nitrogen to extinguish the tire. The firebox ash was then partitcnas into three categories accoraing to its stage of combustion - powder ash. gray asn and black isi-coke - to more carefully scrutinize comouston results. Powder ash consisted of the most weil-burzad. fineiy divided (-1/4 in) material reiatue to the other mo tractions. Gray asn consisted 
of $!=-2=$ ? gieces (plus i/4 in) that generally nad undergone intermediate comoustion. Black asnicoke resu: 20 from the least comoustion, consising primariy of the tuei fed near the end of the test. The parz=cned ash sampies were then separateiy weigned. crusned. ritled, and analyzed.

\section{RESLLTS AND DISCLSSION : Screening : with Hazard $=4$}

Tabie : summarizes pertinent WAF comoustion/emissions resuits ior Hazard \#4 stoker and brictered fuel analogs. The purpose of these tests was to determine if $\mathrm{SO}_{2}$ removais were strongiy depezcent on the type of sorbent (hydrated lime, calcitic limestone, and dolomitic limestone) at a caicum-to-sulfur ratio of approximately 3:1. As incicated in Table 3, sulfur removals for all three briquettes ranged between $36-43 \%$ as calculated from the integrated mass tlow of suifur (as $\mathrm{SO}_{2}$ ) over =:e entire test length and the amount of sulfur in the coal feed. Bed temperatures tluctuated consicerably in the $2000-2700^{\circ} \mathrm{F}$ range and averages were in the $2100-2400 \%$ F range.

Of rote was the sulfur capure for the Hazard \#4 stoker and sorbentiess briquette, which were in the $;-: i 5_{0}$ range due to the incomplete combustion of suifur. Approximately $30-90 \%$ of this "suifur rems: ${ }^{-1}$ " actually resides in the black asidcoke collected in the test. The suifur/carion ratios of the blacs zoke/ash are quite close (within $\pm 30 \%$ ) to the parent indicating similar levels of combustion for tra sulfur-and caroon-containing species. Lltimately, these trends will aid projections of $\mathrm{SO}_{2}$ removais based on a fixed combustion erriciency in iurure repors.

Dupisizie tests found in Table 3 for Hazard $\$ 4$ stoker demonstrate WAF repeatability. Of particular agreament were the key combustion indicators. such as carbon conversion and fuel bed (ash breaiciowns) caking tendencies, and key emissions indicators, such as molar average (ppm) and integsied mass ( $\mathrm{lb} / \mathrm{MMB}$ tu) values. In comparing the Hazard $\$ 4$ stoker and briquetted coal/sorident fueis. :: must be remembered that a strong emphasis was placed on conducting screening tests at near-asmum comoustion conditions within each test day. For this reason, several operating parazeters (e.g., excess air) are not fixed across the Hazard series in Table 3.

As iroscated in Table 3, all the $\mathrm{NO}_{\mathrm{x}}$ emissions were low, in the 0.39-0.55 $\mathrm{lb} \mathrm{NO} / \mathrm{MMBu}$ range, and sintin the DOE goal of $0.6 \mathrm{lb} / \mathrm{MMBr}$ for retrorit combustors. $\mathrm{NO}_{\mathrm{z}}$ emissions averaged from $176-25$ ppm range on a dry basis. This range of $\mathrm{NO}_{\mathrm{r}}$ is comparable to about $10-15 \%$ fuel nitrogen conversion during combustion, assuming that all of the $\mathrm{NO}_{z}$ resulted from fuel nitrogen pathways.

White $\mathrm{NO}_{1}$ emissions were fairiy constant through the Hazard series, $\mathrm{CO}$ and $\mathrm{THC}$ emissions were more variable, in the $181-932 \mathrm{ppm}(0.23-1.50 \mathrm{lb} / \mathrm{MMBtu})$ and $3-16 \mathrm{ppm}(0.004-0.016 \mathrm{lb} / \mathrm{MMBtu})$ range. :espectively. $\mathrm{CO}$ and $\mathrm{THC}$ are extremely sensitive, varying up to an order of magnitude durirg a test. Other species (e.g., $\mathrm{CO}_{2}, \mathrm{O}_{2} . \mathrm{SO}_{2}, \mathrm{NO}$ ) typically tuctuate within $\pm 20-50 \%$ of the mean secause of their more linear relation to the burning rate. $\mathrm{CO}$ and THC emissions. towever. vary irdely as coke forms, fractures, and begins to burn.

Tajis : :eveals that fly ash occurred in a range of about $2-10 \%$ of frebox ash levels as judged from isoki-zric sampling during the Hazard series tests. Lniortunately, particulate sampiing in the WAF is campiicated by a smail diameter stack $(8 \mathrm{in}$ ), fluctuations in stack temperatures, and most impcranuy, ny ash deposition at the rear of the furnace and other unavoidable low veiocity (less than 0 it'sec) areas. Stack cleanings arter 10-15 tests reveaied that deposicion was comparable to 
Sok:az= samping vaiues. Consequenty, reported carticuiate loadings include a multi-test average jepcs:zon factor. Particulate emissions ranged from $0.3-1.4$ ib $\mathrm{MMB}$ M in the Hazard screening ests. $三 20$ there was no apparent tend with soroent inciusion. This is not entirely unexpected given the $i=-$ a number of variables, such as fuel-ieed-partcie size. asin content. comoustion air flow rate, and $:=$-astion efficiency, which influence tiy ash emissions.

\section{Comrasrion/Emissions Trends - Blue Gem. T.vin Branch. Brookrilie. and Pocahontas \#3}

Fror. an Hazard $\# 4$ /sorbent screening results, hydrated lime was selected as the principal sorioent For t:a rext series of briquetted coal/sorbent iueis, based on the ciesire to maximize briquerted fuel heaurg values by minimizing sorbent load with (high-calcium) hydrated lime. Briquetted coaisoroent fueis at $\mathrm{Ca} / \mathrm{S}=3$ were prepared for the Brookville, Pocahontas \#3, Twin Branch. Blue Gem Luw Ash, and Blue Gem Medium Ash: briquetted fuels at $C a / S=2$ and $C a / S=0$ were also precared for the latter three coals. WAF tests were then conducted for all of these fuels.

In severai respects, these WAF tests resuited in trends similar to those found in the Hazard series. For example, $\mathrm{NO}_{z}$ emissions inferred about the same degree (10-15\%) of fuel nitrogen conves:on. Other similarities included the range of bed temperatures, tly ash loadings, and suifur retencon levels for the stoker coais and sorbentiess briquetres. In generai, these findings were in agreement with the literature $[4-6]$. Some of the more important trends are highlighted below.

Figure : summarizes the observed $\mathrm{SO}_{2}$ emissions for these stoker coais and their briquette analogs, althoug it is important to realize the suifur retention factor and its comoustion dependence. Resuis were similar to the Hazard $\# 4$ series with observed $\mathrm{SO}_{2}$ removals in the range of $35-45 \%$ for tra sydrated lime-containing briquetted fueis at $\mathrm{C} / \mathrm{S}=3$. A notable exception occurred with the Blue $\mathrm{Crm}$ Low Ash $\mathrm{Ca} S \mathrm{~S}=3$ fuel, which exnibited a higher $\mathrm{SO}$, removal of $54 \%$. There is no apparez: explanation for this enhancement. The sorbent to coal ash ratio of 6.4 for this Blue Gem Low sin briquetted fuel is substantiaily greater. however. than that found (0.5-1.6 range) in the other zal/sorbent fueis. This may have ied to improved hydrated lime- $\mathrm{SO}_{2}$ interaction by suppressng physical encapsulation of caicium oy inert ash or by reducing chemicai scavenging cue :0 reaszons of calcium oxide with asn species such as silica or alumina

From a process standpoint, the high $\mathrm{SO}_{2}$ removal associated with the low-ash Blue Gem briquetre is enccuraging if advanced coal cleaning couid be integrated with reconstitution schemes to procuce a hign cuaity coal-based fuel. On an energy equivaient basis, the ooserved $\mathrm{SO}_{2}$ emission of 0.48 :b/1ME is very close to the $0.4 \mathrm{lb} / \mathrm{MMBu}$ DOE program goai for new combustors. The Twin Brarca ( $C 2 / S=3$ ) briquette also approached this goal as snown in Figure 3.

The crcuetted coai/sorbent fuels of $\mathrm{C} 3 / \mathrm{S}=2$ had lower $\mathrm{SO}_{2}$ removais. in the $25-35 \%$ range. Of note is tra: ${ }_{1}$ coal/sorbent fuels resulted in $\mathrm{SO}_{2}$ emissions well below the $1.2 \mathrm{lb} / \mathrm{MMBt}$ goal suggested for :-custrial retrotit combustors. From Figure 3,0.6 lb SO $2 \mathrm{KMB}$ is an achievaole goal with low : : :ais of sorbent addition for low-sulfur stoker coals.

As $:: z$ ine Hazard $\$ 4$ series. NO, emissions were tairiy low in most tests, generaily in the $0.3 \cdot 0.6$ .b/M!Bu (as $\mathrm{NO}_{2}$ ) range, and within the target goai of $0.6 \mathrm{lb} \mathrm{NO}$ MMBr for retrotit comoustors. but sinty nigner than the $0.2 \mathrm{lb} . \mathrm{NO} / \mathrm{MMBtu}$ goai sought for new comoustors. The exception was the ? razontas ${ }_{3} 3$ briquette $(0.23 \mathrm{lb} / \mathrm{MMBt}$ as $\mathrm{NO})$ and was projably due to the low ruel-nimogen 
conez: of the parent coal as shown in Tabie 2. Tere was no apparent trend with respect to sorxert inclusion for any of the briquetted fueis.

The =ost signiricant resuit of this WAF test senes was the dramatc improvement in combustion ihar $=$ aristics of the briquetted coaisordent rueis reiative to ine parent stoker coais. These coavsoroent fueis had much more stable ruel beds and had remarkably better ignition and comeusaon qualities as judged from visual ooservations. While the suppression of coal caking iencarcies in the presence of sorbent has been reported in the literarure, it was surprising to observe such erects even at dosages as low as 3-5 wt\% sorbent. To illustrate these observations, severai figures have been prepared. In each case, the briquerted coal/soribent fuels seem superior to even the weij-behaved (in the WAF) Hazard stoker coai reported in Table 3.

Figure + illustrates the suppression in apparent coking tendency with sorbent inclusion, as judged by the black ash/coke formed as a percent of the fed fuel. Figure 5 illustrates the dramatic rise in the weii-burned powder fraction of the firebox ash with sorbent inclusion; this is a consequence of the suporessed coking tendency coupied with the improved ignition rates. In Figures 4 and 5 , it is important to note that these enhancements tar surpass what would be expected (i.e., mass balarice from simple physical addition of finely divided hydrated lime to the parent coals. This point is strongly conveyed in Figure 6 , which shows the improved carbon conversions exhibited by the irsuetted coal/sorbent fuels. Somewhat surprisingly, the increase in carbon conversion actuaily crises sorbent addition in terms of the net treoox asin generated. as shown in Figure 7.

As a :esult of the improved combustion, the coal/sorbent briquetted fuels produced lower emissions of $\mathrm{CO}$ and $\mathrm{THC}$ as shown in Figures 8 and 9 , respecavely. A detailed study of these emissions is uxcer way to develop projected $\mathrm{CO}$ and $\mathrm{THC}$ emissions reductions based on pseudo-steady state assurptions. Preliminary estimates reveal that $\mathrm{CO}$ and THC reductions on the order of $30-50 \%$ are achieves with the briquetted coal/sorbent fuels.

rigures $\div-9$ appear somewhat contradictory in assessing sorbentless briquetted fuel periomance reiacve :o the stoker coals and briquerted coal/sorbent analogs. The combustion indicarors (Figures 4-7) cernitively revealed intermediate improvements over the stoker coais. It is not clear whether this is a particle size effect, in that briquetted fuels produce more ines upon feeding as shown in Figure 2 . or a binder effect. In Figures 8 and 9 , however, $\mathrm{CO}$ and THC emissions from the sorbervess briquettes were higher than that observed with the parent coals. Visual observations incicied that more stable fuel beds were obtained with sorbent-containing briquetted fuels.

From Table 3 , it is interesting to note that while siight carbon conversion improvements $(2-$ percentage points) were observed for the briquerted coal/sorbent fuels in the Hazard series, some of the other trends (e.g., reduced coke tomation) were absent. These subtle discrepancies are probasiv the result of the inherent low-caking $(F S I=i .5)$ tendency of the Hazard parent stoker coai.

Interstation of carbon conversions and other parameters in Figures 4-9 should not be used to extriooiate direct parent coal comparisons. There is no issue more divided in the small-underteed stoke it:erature than the "reported" compatibiiity of caking coais. Many reports note the influence of many variables such as fuel particie size distribution, heat-release rate, fuel moisture, and most :mecrantiy, stoker (feedscrew, retor) design. For tis reason, interpretations need to be made in a generaj context within each parent coal series. A key point here was that. in every case, the 
Jriqueres coal/sorbent fuei periormance resuited in simpier stoker operation in terms of fuei lightoff ind zed stability; in short. these fueis bumed more easiyy, zaquiring less operator attention.

\section{SU.HYLARY}

The assoiute carbon conversions tor ail briquetted coai/sorbent fueis were greater than 92\%, and in the $55.98 \%$ range for most cases. which is excellent tor a smail-underteed stoker. Larger-scaie and longer-term testing is needed to assess reai-life benerits for commercial feasibility. In economic :erms. :cremental fuel cost would be reasonable at about $\$ 1.5 /$ ton and \$0.14/MMBtu for a typical $\$ 35 / t 0 n .13000 \mathrm{Btu} / \mathrm{lb}$ coal and $5 \mathrm{wt} \%$ hydrated lime addition. The imoroved combustion characteristics as well as modest emissions reductions in $\mathrm{SO}_{2}, \mathrm{CO}$. and $\mathrm{THC}$ are worth considering in future ine coal recovery/reconstitution schemes with stoker market intentions.

WAF emissions testing will be completed for remaining coal/sorbent briquettes. Larger-scaie emissions tests are planned in a commercial 2.6 MMBtu/hr cast-iron boiler for stoker coals and any promising coal/sorbent fuels identified in the WAF screening study. A detailed topicai report is being prepared.

\section{DISCLHIMER}

References to any specific commercial product. process. or service is for understanding purposes oniy ara does not imply endorsement or favoring by the Linited States Department of Energy.

\section{REFERENCES}

[1] 2OE/PETC Program Research and Development Announcement NO. DE-RA22-88PC\$8869, Emissions Control for Small-Scale Comoustors. April 6. 1988.

[2] Trivate communications with various L.S. coai companies.

[3] I.C. Freeman. H.W. Pennine. J.I. Jouber, and P.A. Vore, "Emissions Screening of Cual/Sorbent Fueis." Proceedings of the $22^{\text {na }}$ Instinte of Briquetting and Aggiomeration Conference, San Antonio, Texas, November 3-6, 1991 (in press).

[4] 3.W. Rising, H.N. Conkle. W.J Dawson, and R.D. Litt. "Advanced Development of Cuajimestone Fuel Pellet for Industrial Boilers," Battelle-Columbus Laboratories, EPA Contract o. 68-02-3189, September. 1983.

[5] R.E. Dougias, G.E. Wasson. and W.C. Corder, "Stoker Boiler Operadions with Briquerted Cal Fines." Proceedings, Current Developments in Solid Fuel Combustion Systems. Zuuncil of Industrial Boiler Owners Conference, May 8-9. 1990.

[6] Emissions and Their Control from Industrial Instailacons Lsing Solid Fueis: Progress Reoor in. 3. Julv-December. 1990. British Coal Corporation. Coal Research Establishment. Gioucestershire. United Kingdom. 1990. 
Table 2: Briquetted Coal/Sorbent Formulatlons and Characteristics

\begin{tabular}{|lcccccc|}
\multicolumn{1}{c}{-azard $\# 4$} & \multicolumn{3}{c}{ Composition $(w t \%)$} & \multicolumn{2}{c|}{ Laboratory Strength } & HHV Btu/b \\
\cline { 2 - 7 } \multicolumn{1}{c|}{} & Coal & Starch & Sord & Comoress & Drop $(6 \mathrm{ft})$ & $\%$ of Parent \\
\hline Blarik & 96.0 & 4.0 & 0.0 & 24.4 & 93.3 & 99.0 \\
Hyorated Lime, Ca/S=3 & 89.3 & 4.0 & 6.7 & 18.0 & 93.2 & 92.8 \\
Dolomitic LS, Ca/S=3 & 85.5 & 4.0 & 10.5 & 27.0 & 92.9 & 89.1 \\
Calcitic LS, Ca/S=3 & 85.5 & 4.0 & 10.5 & 14.8 & 34.6 & 91.4 \\
\hline
\end{tabular}

Eive Gem Low

\begin{tabular}{|lllllll|}
\hline Blank & 97.0 & 3.0 & 0.0 & 24.6 & 96.2 & 98.6 \\
Hycraied Lime, Ca/S=2 & 92.5 & 4.0 & 3.5 & 19.8 & 92.7 & 95.6 \\
Hycrated Lime, Ca'S=3 & 90.8 & 4.0 & 5.2 & 21.2 & 90.6 & 93.0 \\
\hline
\end{tabular}

Elue Gem Med

\begin{tabular}{|lllllll|}
\hline Blanx & 97.0 & 3.0 & 0.0 & 18.2 & 96.1 & 99.3 \\
Hyorated Lime, Ca/S=2 & 92.5 & 4.0 & 3.5 & 25.4 & 97.5 & 96.3 \\
Hydrated Lime, Ca/S=3 & 90.8 & 4.0 & 5.2 & 21.9 & 96.1 & 94.3 \\
\hline
\end{tabular}

- in Branch

\begin{tabular}{|lllllll|}
\hline Blarix & 97.0 & 3.0 & 0.0 & 11.7 & 89.7 & 96.5 \\
Hyaraied Lime, Ca/S=2 & 93.1 & 4.0 & 2.9 & 19.2 & 96.0 & 94.7 \\
Hydra:ed Lime, Ca/S=3 & 91.7 & 4.0 & 4.3 & 13.6 & 86.1 & 90.9 \\
\hline
\end{tabular}

Erookville

\begin{tabular}{|c|c|c|c|c|c|c|}
\hline Hyaraied Lime, $\mathrm{Ca} / \mathrm{S}=3$ & 89.6 & 4.0 & 6.4 & 23.8 & 98.2 & 94.6 \\
\hline Fxahontas \#3 & & & & & & \\
\hline Hyorated Lime, $\mathrm{C} a / \mathrm{S}=3$ & 90.8 & 4.0 & 5.2 & 20.0 & 100.0 & 90.6 \\
\hline
\end{tabular}


Table 3: WAF Screening Resuits Hazard Stoker and Briquetted Fueis

\begin{tabular}{|c|c|c|c|c|c|c|}
\hline FLE: TYPE & STOKE | & STCKE & $\begin{array}{l}\text { BRIOU } \\
\text { ILSTN }\end{array}$ & $\begin{array}{l}\text { 3RIQU } \\
\text { HYLIM }\end{array}$ & BRIQU & $\begin{array}{l}\text { BRIQU } \\
\text { CLSTN }\end{array}$ \\
\hline $\begin{array}{l}\text { FUE: =EED RATE (LB/HR) } \\
\text { FIANG RATE IN } 1000 \text { BTU/HR }\end{array}$ & $\begin{array}{r}14.4 \\
.44\end{array}$ & $\begin{array}{r}: 2.8 \\
: 63\end{array}$ & $\begin{array}{l}: 3.7 \\
: 54\end{array}$ & $\begin{array}{r}13.4 \\
157\end{array}$ & $\begin{array}{l}i 2.5 \\
i 58\end{array}$ & $\begin{array}{l}: 3.8 \\
: 59\end{array}$ \\
\hline $\begin{array}{l}\text { CONBUSTION AIR (LB/HR) } \\
\text { OVEAFIRE AIR (LB/HR) } \\
\text { TOTAL AIR (LB/HR) }\end{array}$ & $\begin{array}{r}195 \\
47 \\
242\end{array}$ & $\begin{array}{r}+95 \\
43 \\
238\end{array}$ & $\begin{array}{r}176 \\
47 \\
223\end{array}$ & $\begin{array}{r}172 \\
48 \\
220 \\
\end{array}$ & $\begin{array}{r}192 \\
70 \\
262 \\
\end{array}$ & $\begin{array}{r}203 \\
44 \\
248\end{array}$ \\
\hline $\begin{array}{l}\% \text { EXCESS COMBUSTION AIR } \\
\% \text { EXCESS AIR } \\
\% \text { OVERFIRETOTAL AIR }\end{array}$ & $\begin{array}{r}76 \\
118 \\
19\end{array}$ & $\begin{array}{l}56 \\
90 \\
18\end{array}$ & $\begin{array}{l}32 \\
67 \\
29\end{array}$ & $\begin{array}{l}32 \\
69 \\
22\end{array}$ & $\begin{array}{r}66 \\
127 \\
27\end{array}$ & \begin{tabular}{l|l|}
51 & 1 \\
84 & 1 \\
18
\end{tabular} \\
\hline 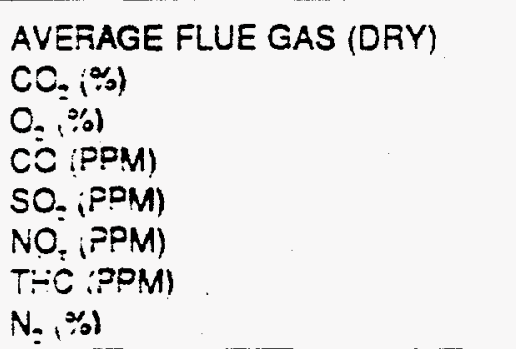 & \begin{tabular}{r|}
3.1 \\
10.5 \\
816 \\
411 \\
202 \\
7 \\
80.3
\end{tabular} & \begin{tabular}{r|}
9.2 \\
10.0 \\
361 \\
485 \\
200 \\
3 \\
90.6
\end{tabular} & \begin{tabular}{r|}
9.9 \\
0.4 \\
391 \\
305 \\
225 \\
3 \\
79.6
\end{tabular} & $\begin{array}{r}9.7 \\
10.1 \\
181 \\
336 \\
176 \\
3 \\
80.2\end{array}$ & \begin{tabular}{r|}
7.6 \\
11.8 \\
932 \\
373 \\
194 \\
16 \\
30.4
\end{tabular} & \begin{tabular}{r|}
3.8 \\
$i 0.7$ \\
761 \\
313 \\
226 \\
15 \\
30.3
\end{tabular} \\
\hline MOLE $\% \mathrm{H}_{2} \mathrm{O}$ (est) & 3.6 & 4.21 & 5.4 & 5.5 & 4.61 & 5.2 \\
\hline $\begin{array}{l}\text { LE.MMBTU (FUEL) } \\
\text { CO } \\
\text { SC: } \\
\text { NO, as } \mathrm{NO}_{2} \\
T-\mathrm{C} \times 100\end{array}$ & $\begin{array}{l}1.35 \\
.45 \\
0.53 \\
0.80\end{array}$ & $\begin{array}{l}0.54 \\
1.50 \\
0.46 \\
0.74\end{array}$ & \begin{tabular}{l|}
0.59 \\
0.94 \\
0.52 \\
0.79
\end{tabular} & $\begin{array}{l}0.28 \\
1.00 \\
0.39 \\
0.40\end{array}$ & $\begin{array}{l}1.50 \\
i .34 \\
0.52 \\
1.53\end{array}$ & $\begin{array}{l}i .15 \\
. .22 \\
0.55 \\
1.56\end{array}$ \\
\hline CAREON CONVERSION $(\%)$ & $90.9 !$ & $90.4 !$ & 95.21 & 92.41 & 92.7 & 85.5 \\
\hline SULFUR REMOVAL (\%) & 3.5 & 7.1 & 43.11 & 38.0 & 11.0 & 36.5 \\
\hline $\begin{array}{l}\text { ASH GENERATED (\% of fuel) } \\
\text { POWDER/FUEL FED } \\
\text { GRAYIFUEL FED } \\
\text { COKEFUEL FED }\end{array}$ & $\begin{array}{r}16.6 \\
7.1 \\
3.6 \\
6.0\end{array}$ & $\begin{array}{r}16.6 \\
6.8 \\
5.2 \\
4.6\end{array}$ & \begin{tabular}{r|}
18.0 \\
8.6 \\
5.0 \\
4.4
\end{tabular} & $\begin{array}{r}16.8 \\
7.4 \\
4.6 \\
4.8\end{array}$ & $\begin{array}{r}14.3 \\
8.0 \\
0 \\
6.3\end{array}$ & $\begin{array}{r}16.7 \\
9.0 \\
3.5 \\
4.3\end{array}$ \\
\hline $\begin{array}{l}\text { ASH BREAKDOWN (\%) } \\
\text { POWDER/FIREBOX } \\
\text { GAAYIFIREBOX } \\
\text { COKEFIREBOX }\end{array}$ & \begin{tabular}{l|}
42 \\
21 \\
36
\end{tabular} & \begin{tabular}{l|l}
41 \\
-2 \\
27
\end{tabular} & \begin{tabular}{l|}
48 \\
29 \\
24
\end{tabular} & $\begin{array}{l}44 \\
27 \\
29\end{array}$ & $\begin{array}{r}56 \\
0 \\
44\end{array}$ & $\begin{array}{l}54 \\
21 \\
26\end{array}$ \\
\hline $\begin{array}{l}\text { RATIO FLYIFIREBOX ASH } \times 100 \\
\text { LB PARTICULATEIMMBTU }\end{array}$ & $\begin{array}{l}2.91 \\
0.38\end{array}$ & $\begin{array}{l}5.47 \mid \\
0.71\end{array}$ & $\begin{aligned}-.83 \\
0.77\end{aligned}$ & $\begin{array}{l}2.18 \\
0.31\end{array}$ & $\begin{array}{l}8.90 \\
1.00\end{array}$ & $\begin{array}{l}9.57 \\
.38\end{array}$ \\
\hline
\end{tabular}



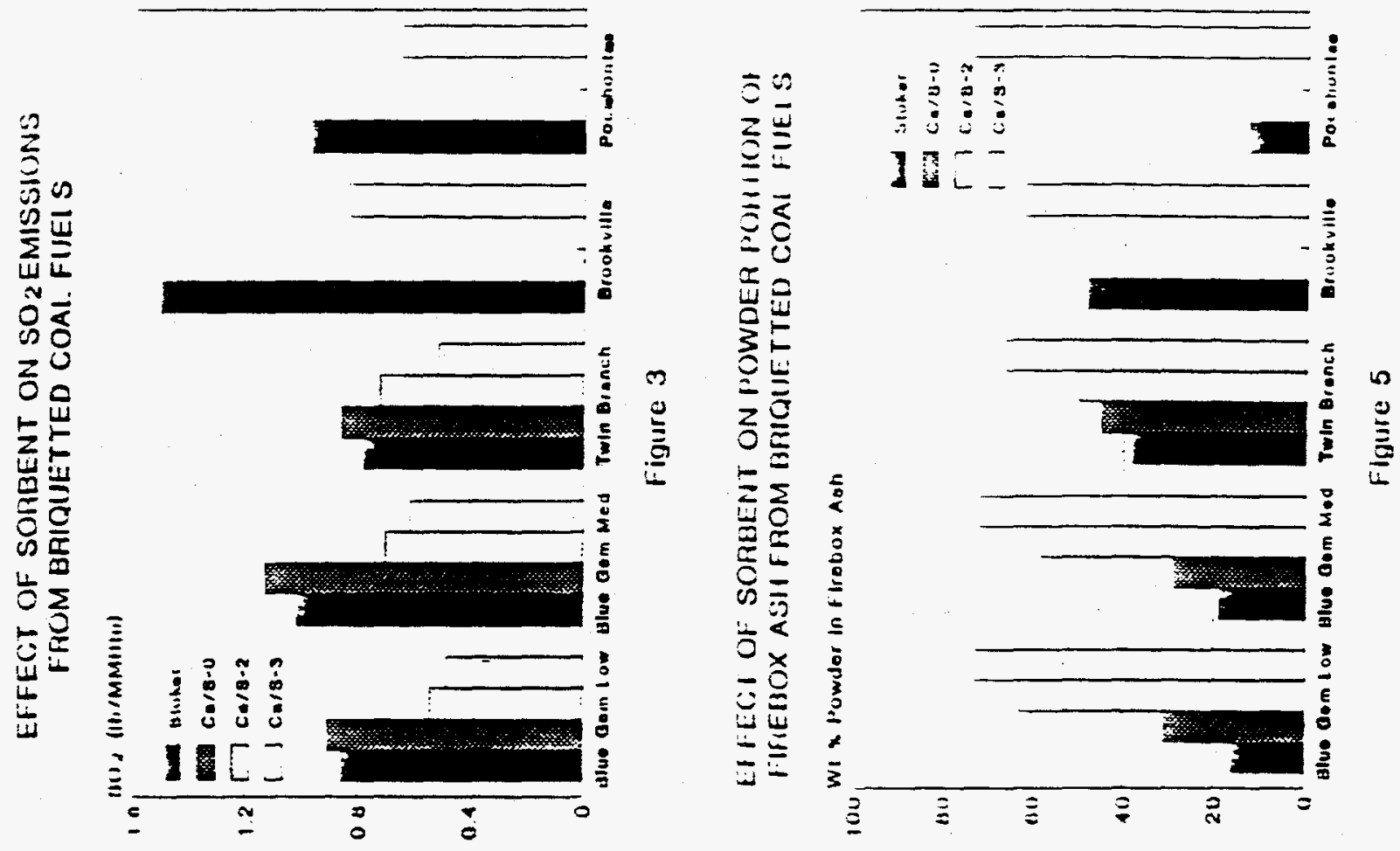

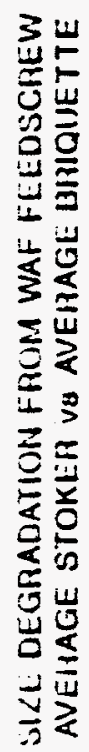
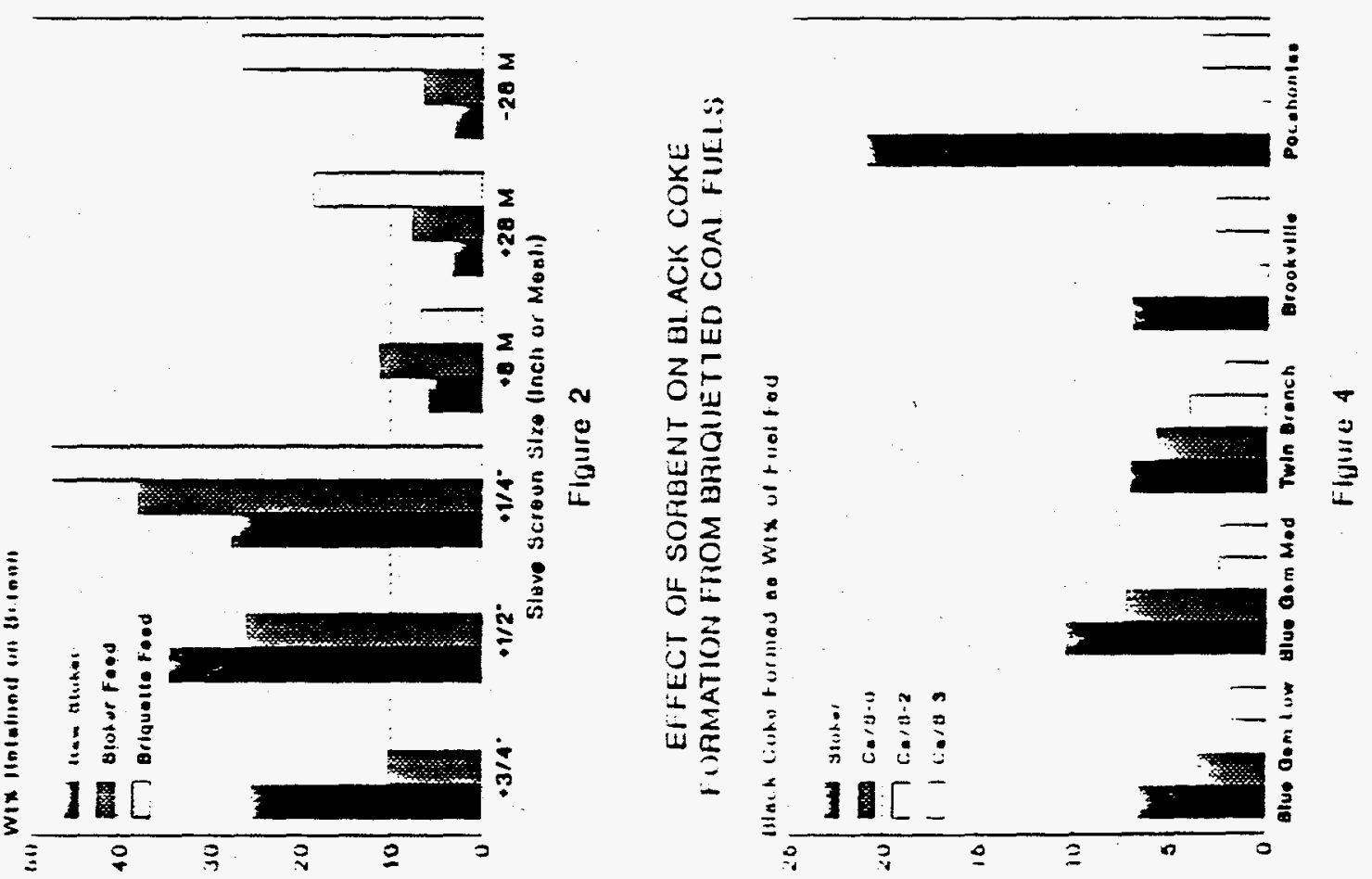

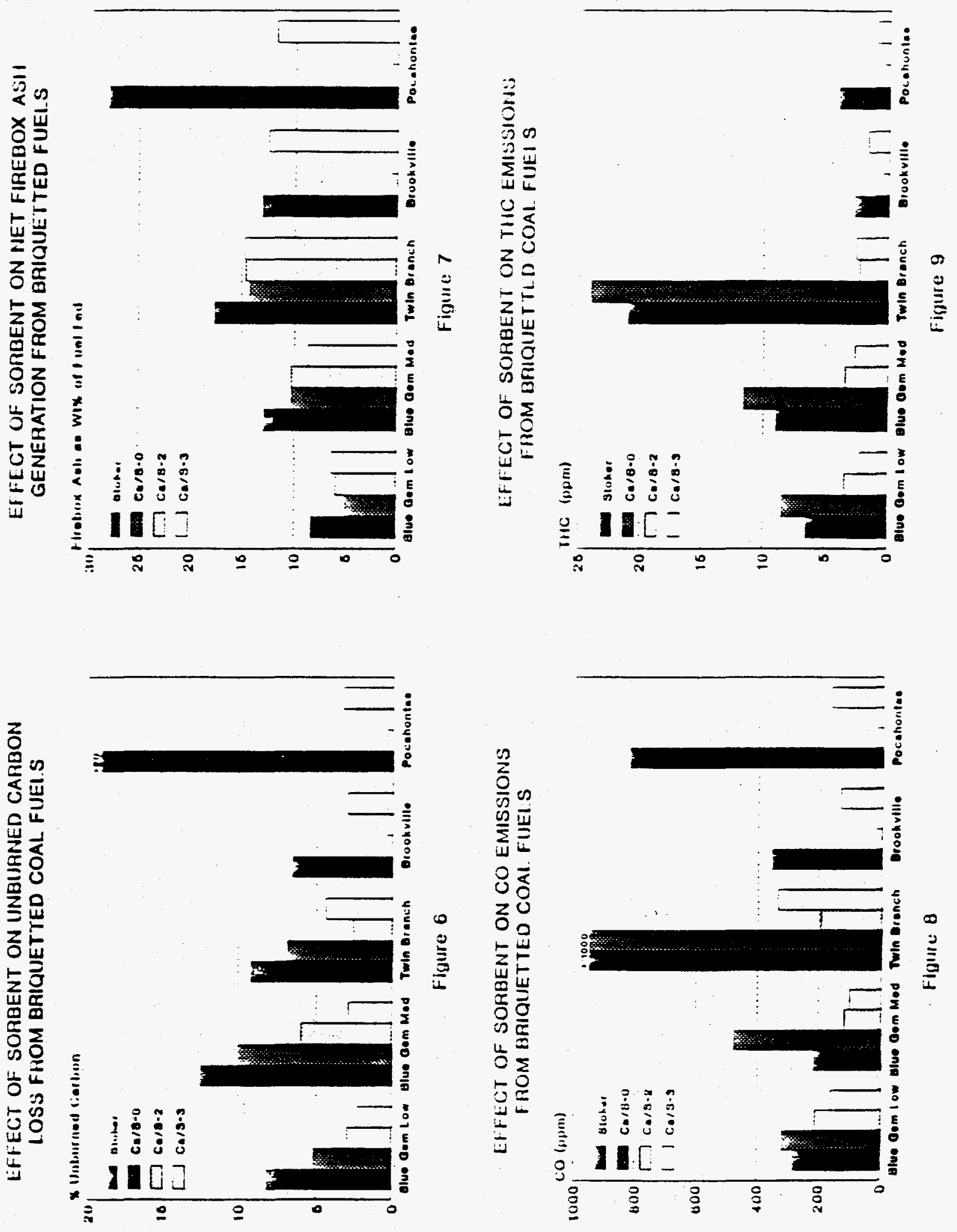